San Jose State University

SJSU ScholarWorks

Mineta Transportation Institute Publications

4-2020

\title{
The Geographic Disparities in Transportation-Related Physical Activity in the United States: An Analysis of the 2017 NHTS Data
}

Hongwei Dong

California State University, Fresno

Follow this and additional works at: https://scholarworks.sjsu.edu/mti_publications

Part of the Environmental Public Health Commons, and the Other Civil and Environmental Engineering Commons

\section{Recommended Citation}

Hongwei Dong. "The Geographic Disparities in Transportation-Related Physical Activity in the United States: An Analysis of the 2017 NHTS Data" Mineta Transportation Institute Publications (2020). https://doi.org/10.31979/mti.2020.1912

This Report is brought to you for free and open access by SJSU ScholarWorks. It has been accepted for inclusion in Mineta Transportation Institute Publications by an authorized administrator of SJSU ScholarWorks. For more information, please contact scholarworks@sjsu.edu. 


\section{SJSU}

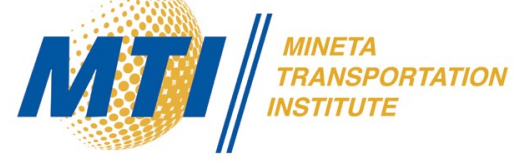

The Geographic Disparities in Transportation-Related Physical Activity in the United States: An Analysis of the 2017 NHTS Data

Hongwei Dong, PhD

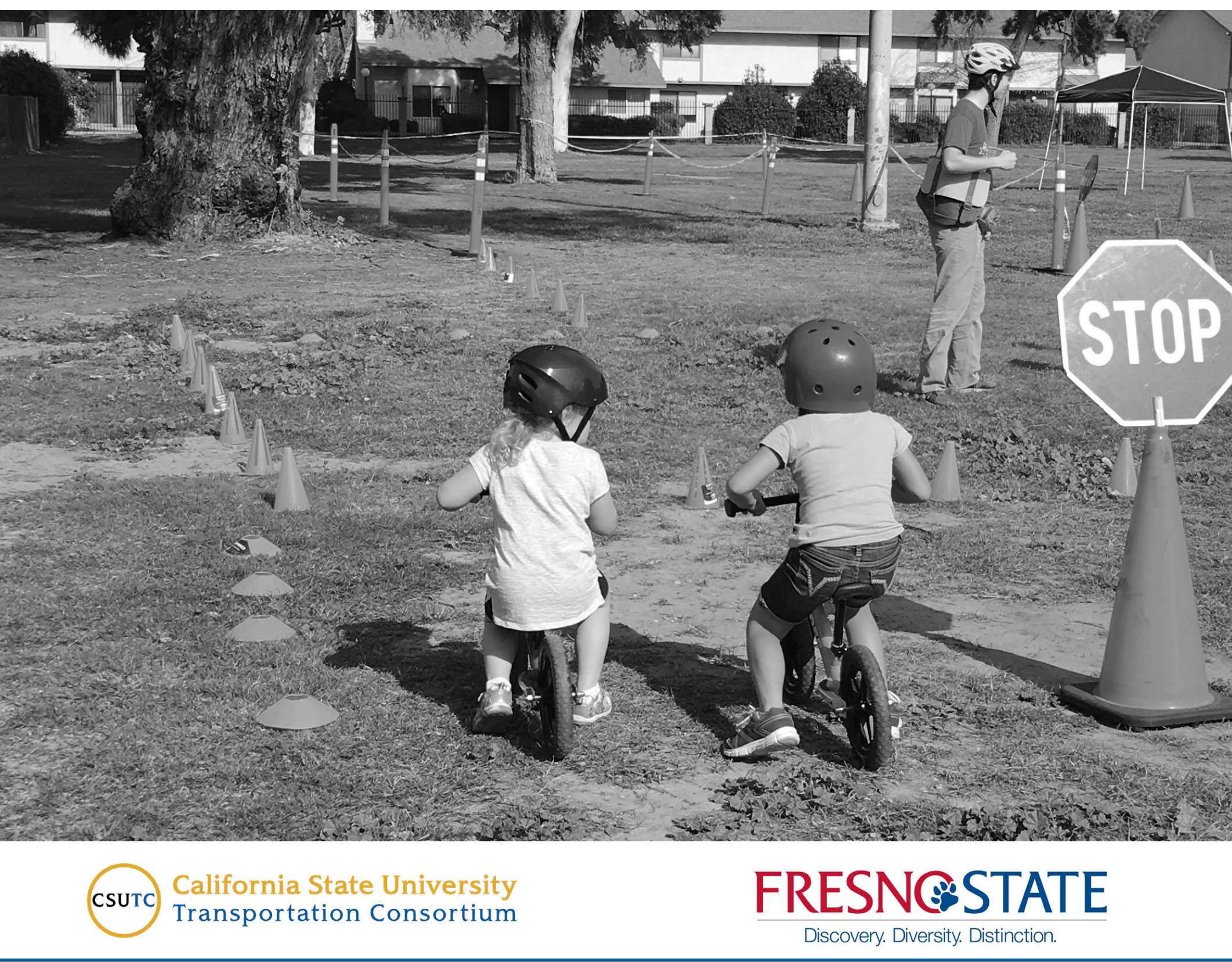




\section{MINETA TRANSPORTATION INSTITUTE}

Founded in 199I, the Mineta Transportation Institute (MTI), an organized research and training unit in partnership with the Lucas College and Graduate School of Business at San José State University (SJSU), increases mobility for all by improving the safety, efficiency, accessibility, and convenience of our nation's transportation system. Through research, education, workforce development, and technology transfer, we help create a connected world. MTI leads the four-university. MTI leads the four-university California State University Transportation Consortium funded by the State of California through Senate Bill I.

MTl's transportation policy work is centered on three primary responsibilities:

\section{Research}

MTI works to provide policy-oriented research for all levels of government and the private sector to foster the development of optimum surface transportation systems. Research areas include: bicycle and pedestrian issues; financing public and private sector transportation improvements; intermodal connectivity and integration; safety and security of transportation systems; sustainability of transportation systems; transportation / land use / environment; and transportation planning and policy development. Certified Research Associates conduct the research. Certification requires an advanced degree, generally a Ph.D., a record of academic publications, and professional references. Research projects culminate in a peer-reviewed publication, available on TransWeb, the MTI website (http://transweb.sjsu.edu).

\section{Education}

The Institute supports education programs for students seeking a career in the development and operation of surface transportation systems. MTI, through San José State University, offers an AACSBaccredited Master of Science in Transportation Management and graduate certificates in Transportation Management, Transportation Security, and High-Speed Rail Management that serve to prepare the nation's transportation managers for the 2 I st century. With the active assistance of the California Department ofTransportation (Caltrans), MTI delivers its classes over a state-of-the-art videoconference network throughout the state of California and via webcasting beyond, allowing working transportation professionals to pursue an advanced degree regardless of their location. To meet the needs of employers seeking a diverse workforce, MTl's education program promotes enrollment to under-represented groups.

\section{Information and Technology Transfer}

MTI utilizes a diverse array of dissemination methods and media to ensure research results reach those responsible for managing change. These methods include publication, seminars, workshops, websites, social media, webinars, and other technology transfer mechanisms. Additionally, MTI promotes the availability of completed research to professional organizations and journals and works to integrate the research findings into the graduate education program. MTl's extensive collection of transportation- related publications is integrated into San José State University's world-class Martin Luther King, Jr. Library.

\section{Disclaimer}

The contents of this report reflect the views of the authors, who are responsible for the facts and accuracy of the information presented herein. This document is disseminated in the interest of information exchange. The report is funded, partially or entirely, by a grant from the State of California. This report does not necessarily reflect the official views or policies of the State of California or the Mineta Transportation Institute, who assume no liability for the contents or use thereof. This report does not constitute a standard specification, design standard, or regulation. 
REPORT 20-11

\section{THE GEOGRAPHIC DISPARITIES IN TRANSPORTATION-RELATED PHYSICAL ACTIVITY IN THE UNITED STATES: AN ANALYSIS OF THE 2017 NHTS DATA}

Hongwei Dong, PhD

April 2020

A publication of

Mineta Transportation Institute

Created by Congress in 1991

College of Business

San José State University

San José, CA 95192-0219 


\section{TECHNICAL REPORT DOCUMENTATION PAGE}

1. Report No. 20-10

4. Title and Subtitle

The Geographic Disparities in Transportation-Related Physical Activity in the United States: An Analysis of the 2017 NHTS Data

7. Authors

Hongwei Dong, PhD, https://orcid.org/0000-0002-7614-169X

2. Government Accession No.
3. Recipient's Catalog No.

5. Report Date

April 2020

6. Performing Organization Code

8. Performing Organization Report CA-MTI-1912

10. Work Unit No.

11. Contract or Grant No. ZSB12017-SJAUX

San José State University

San José, CA 95192-0219

12. Sponsoring Agency Name and Address

State of California SB1 2017/2018

Trustees of the California State

University

Sponsored Programs Administration

401 Golden Shore, 5th Floor

Long Beach, CA 90802

15. Supplemental Notes

DOI: $10.31979 / \mathrm{mti} .2020 .1912$

\section{Abstract}

Research on the relationship between urbanicity and physical activity yielded mixed results despite many studies consistently showing that residents tended to undertake more transportation-related physical activity in a more urban environment. This study analyzed the 2017 NHTS data to examine the geographic disparities in physical activity, particularly transportation-related physical activity in the United States. Our analysis suggests the relationship between urbanicity and physical activity demonstrates a flat U-shape in graphed data. Residents are more physically active when they live in the areas from the two ends of the urbanization spectrum: inner cities and inner suburbs of large metropolitan areas and the rural parts of non-metropolitan areas. Suburbanites, particularly mid-ring and outer-ring suburbanites walk the least. Only very slight geographic variation exists in the weekly rates of walk and bike trips that are strictly for exercise. The study revealed greater variation of the weekly rates of walk and bike trips that are for non-exercise purposes. This study suggests a more complicated relationship between urbanicity, active travel, and physical activity in a broader geographic context. More research needs to examine whether and how new urbanist design can promote active travel, particularly active travel strictly for exercise, in rural areas and areas of low urbanicity.

\section{Key Words}

Spatial analysis, health, equity, travel patterns, travel surveys

\section{Distribution Statement}

No restrictions. This document is available to the public through The National Technical Information Service, Springfield, VA 22161
19. Security Classif. (of this report) Unclassified
20. Security Classif. (of this page) Unclassified
21. No. of Pages

36
22. Price 


\title{
Copyright $\odot 2020$ \\ by Mineta Transportation Institute \\ All rights reserved
}

\section{DOI: \\ 10.31979/mti.2020.1912}

\author{
Mineta Transportation Institute \\ College of Business \\ San José State University \\ San José, CA 95192-0219 \\ Tel: (408) 924-7560 \\ Fax: (408) 924-7565 \\ Email: mineta-institute@sjsu.edu
}

transweb.sjsu.edu 


\section{ACKNOWLEDGMENTS}

The author would like to thank Fresno State University graduate student Gideon Marsh, who participated in the study as a student assistant. The author is grate-ful to the Fresno State Transportation Institute (FSTI), particularly the director Dr. Aly Tawfik and FSTI staff members Melanie Allen, Rebecca Kaaz, and Dr. Eazaz Sadeghvaziri. The author is also thankful to the FHWA NHTS Program for granting access to the 2017 NHTS locational data.

The authors thank Editing Press, for editorial services, as well as MTI staff, including Executive Director Karen Philbrick, PhD; Deputy Executive Director Hilary Nixon, PhD; Graphic Designer Alverina Eka Weinardy; and Executive Administrative Assistant Jill Carter. 


\section{TABLE OF CONTENTS}

$\begin{array}{ll}\text { Executive Summary } & 1\end{array}$

I. Introduction 3

$\begin{array}{ll}\text { II. Literature Review } & 4\end{array}$

$\begin{array}{ll}\text { III. Data and Methods } & 7\end{array}$

$\begin{array}{lr}\text { Data } & 7\end{array}$

$\begin{array}{lr}\text { Measurement } & 7\end{array}$

$\begin{array}{ll}\text { Modeling techniques } & 12\end{array}$

IV. Results and Findings 14

$\begin{array}{ll}\text { Descriptive analysis } & 14\end{array}$

$\begin{array}{ll}\text { Modeling analysis } & 15\end{array}$

$\begin{array}{ll}\text { Barriers to walking and biking more } & 24\end{array}$

$\begin{array}{ll}\text { V. Conclusion } & 26\end{array}$

$\begin{array}{lr}\text { Abbreviations and Acronyms } & 28\end{array}$

Endnotes $\quad 29$

$\begin{array}{ll}\text { Bibliography } & 32\end{array}$

$\begin{array}{ll}\text { About the Authors } & 35\end{array}$

$\begin{array}{ll}\text { Peer Review } & 36\end{array}$ 


\section{LIST OF FIGURES}

1. Eight Geographic Locations 12

2. Geographic Variation of Physical Activity 15

3. Barriers to Walking and Biking More 25 


\section{LIST OF TABLES}

1. A Summary of Relevant Literature $\quad 5$

2. Descriptive Statistics of Variables 9

$\begin{array}{ll}\text { 3. Results of the Full Models } & 18\end{array}$ 


\section{EXECUTIVE SUMMARY}

Research on the relationship between urbanicity and physical activity has yielded mixed results, despite many studies consistently showing that residents tend to undertake more transportation-related physical activity in a more urban environment. The purpose of this study is to examine the geographic disparities in transportation-related physical activity at finer geographic scales in the entire nation, with and without controlling for the built and social environment at the neighborhood level.

This study takes advantage of several new questions that were added to the 2017 National Household Travel Survey (NHTS) regarding people's physical activity and their walking and bike trips that were strictly for exercise. Unlike previous studies that adopted a dichotomous urban-rural variable, this analysis categorizes residents into eight geographic locations: four in large metropolitan areas (downtown, inner-ring suburb, mid-ring suburb, and outer-ring suburb), two in small metropolitan areas (urban and rural), and two in non-metropolitan areas (urban and rural). The researchers conducted both descriptive and modeling analyses to evaluate the intra- and inter-metropolitan patterns of physical activity and active travel in the United States. The researchers also differentiated walk and bike trips that were strictly for exercise from walk and bike trips undertaken for other purposes

This study shows that the relationship between urbanicity and physical activity demonstrates a flat U-shape. Residents were more physically active when they lived in areas from the two ends of the urbanization spectrum: inner cities and inner suburbs of large metropolitan areas and the rural parts of non-metropolitan areas. Suburbanites, particularly mid-ring and outer-ring suburbanites, walked the least. The geographic pattern holds regardless of the inclusion of neighborhood characteristics in the models. There is very slight geographic variation in the weekly rates of walking and bike trips that are strictly for exercise. There is much more variation of the weekly rates of walk and bike trips that are undertaken for non-exercise purposes.

Walkers and cyclists in the eight different geographic locations reported different infrastructure and safety barriers that kept them from walking and biking more. For cyclists in the central cities of large metropolitan areas and cyclists in non-metropolitan areas, a lack of nearby paths or trails was the prominent infrastructural barrier to biking more. For suburbanites, a lack of nearby parks seemed to be a more prominent barrier to biking more. No matter which geographic location they lived in, walkers consistently reported no sidewalks or sidewalks in poor condition as the most prominent barriers to walking more. The sidewalk issue was more serious for walkers in suburbs and the urban parts of small metropolitan areas than for walkers in other locations. Insufficient lighting at night was consistently reported as the most prominent safety barrier to walking more in various geographic locations.

The findings from this study contribute to evidence-based planning of active transportation and public health interventions. Suburban areas in large metropolitan areas seem to be the least physically active places and have the largest potential for improvement. Even incremental improvements in suburbs will generate huge public health benefits, given that more than half of Americans live in suburbs. Specifically, addition to or improvement of the quality of sidewalks in suburban neighborhoods seems to be a promising strategy, given 
that suburban walkers reported no sidewalks or sidewalks in poor conditions as the most prominent barriers that keep them from walking more. Improving street lighting seems to be a promising strategy to encourage more walking in urban, suburban, and rural areas. Traffic calming and good lighting at night are two potentially effective tools to encourage more biking in urban and rural areas, respectively. Rural residents take more walks outside than mid-ring and outer-ring suburbanites. Most extant studies of active travel have focused on urban and suburban residents. Our understanding of rural residents' active travel and physical activity is limited. More research needs to study how rural residents travel in non-motorized modes and how they manage to take more walking trips than mid-ring and outer-ring suburbanites. 


\section{INTRODUCTION}

Research has revealed significant geographic disparities in the prevalence of chronic diseases such as overweight, obesity, and diabetes. ${ }^{1}$ It is widely recognized that physical inactivity is a major cause of chronic diseases ${ }^{2}$ and physical exercise is a principal intervention for the prevention thereof. ${ }^{3}$ However, it is unclear whether the geographic health disparities are a result of differing levels of physical activity in different geographic locations. ${ }^{4}$ On the one hand, numerous studies consistently showed that people are more likely to choose active travel modes such as walking and biking in urban environments with higher levels of density and mixed land use as well as better infrastructure for non-motorized travel. ${ }^{5}$ On the other hand, studies of the relationship between urbanicity and physical activity have yielded mixed results. ${ }^{6}$ The purpose of this study is to examine the geographic disparities in transportationrelated physical activity in the United States by utilizing a nationally representative survey, the 2017 National Household Travel Survey (NHTS). ${ }^{7}$

This study takes advantage of a few new questions that were added to the 2017 NHTS to collect information about people's physical activity in a typical week and their walk and bike trips that were strictly for exercise in the past seven days. The researchers also obtained access to the restricted version of the 2017 NHTS data set, which allowed the researchers to locate the home addresses of survey respondents at the Census block group level. The researchers conducted both descriptive and modeling analyses to evaluate the intra- and inter-metropolitan patterns of physical activity and active travel in the United States.

This study is different from previous studies in several ways. Most existing studies of transportation-related physical activity relied on survey data that were collected at local levels. The geographic limitation of these data prevented researchers from identifying inter-regional variation of active travel in the entire nation. Many of these studies adopted a dichotomous urban-rural variable to represent geographic patterns, ignoring the heterogeneity within urban and rural areas. Moreover, many travel survey data were collected through a singleday travel diary because multiple-day travel surveys were expensive to carry out. Research showed that non-motorized trips tend to demonstrate large day-to-day intra-personal variation and a single-day survey may not be able to reveal accurate trip frequency information from non-motorized travel modes. ${ }^{8}$ The 2017 NHTS data is a nationally representative sample that is uniquely suitable to analyze the geographic patterns of active travel and physical activity across multiple geographic scales in the entire nation. The large sample size and the authors' access to the restricted data allowed for movement beyond the urban-rural dichotomy and facilitated analyses at finer geographic scales. Further, the 2017 NHTS asked respondents how many walk and bike trips they took in the past seven days. The seven-day period is long enough to capture the walk and particularly bike trips that were undertaken by infrequent walkers and cyclists. ${ }^{9}$ More importantly, the survey asked respondents how many walk and bike trips they took in the past seven days strictly for exercise. To the best knowledge of the research team, few national survey data sets specifically identify walk and bike trips that are strictly for exercise.

The remainder of the paper is organized as follows. The authors review relevant literature in the next section. Section 3 introduces the data and research methods. Section 4 reports analysis results. Section 5 is a concluding section. 


\section{LITERATURE REVIEW}

The author reviewed 19 empirical studies that explicitly included geographic disparities in physical activity in their research questions. All of them were published after 1999, and 11 of them were conducted in the United States. Half focused on general physical activity, and the other half concentrated on transportation-related physical activity, mainly walking. Table 1 presents a summary of these studies.

Some of these studies reported similar or no differences in the amount of physical activity between urban and rural residents. For example, a study by Tribby and Tharp is one of the few existing studies that used the 2017 NHTS data to compare weekly bicycling rates in urban and rural areas of seven density categories. ${ }^{10}$ Their analysis showed that in the United States, urban and rural residents were not statistically different in terms of their weekly use of bicycles, for all purposes or for exercise only. Carlson and colleagues analyzed the 2015 National Health Interview Survey data in the United States. ${ }^{11}$ Their analysis showed that in the United States, urban and rural residents spent similar amount of time on walking. A study in Scotland showed that urban residents undertook more active travel than rural residents but the difference was mainly due to their different demographics. ${ }^{12}$ Two national studies in Australia suggested that a similar group of variables could predict the amount of physical activity that people undertook regardless of where they lived. ${ }^{13}$ A study in Queensland, Australia found that achieving the recommended amount of physical activity did not vary by geographic location within the region. ${ }^{14}$

Other studies found significant geographic differences in physical activity. Among these studies, most of them showed that urban residents were more physically active. A study of youth in three middle schools in southern states in the United States showed that rural youth undertook less moderate-to-vigorous physical activity than urban youth. ${ }^{15} \mathrm{~A}$ national study of American adolescents also showed that among the adolescents living in suburbs, those in older neighborhoods were more physically active than those in newer neighborhoods. ${ }^{16}$ Martin and colleagues analyzed the 2000 Behavioral Risk Factor Surveillance System (BRFSS) data and found that urban residents undertook more physical activity than residents in rural areas and the urban-rural difference in physical activity was stronger in southern states. ${ }^{17}$ Parks et al. compared low-income residents in urban, suburban, and rural areas in the United States. ${ }^{18}$ They found that low-income residents in suburban were more likely to meet the recommendation for physical activity, while low-income residents in rural areas were the least likely to meet the recommendation. Wilcox et al. studied leisure time physical activity undertaken by women of 40 years and older in the United States. ${ }^{19}$ They found that urban women were more physically active than rural women and such a difference tended to be more striking in southern states and among less educated women. At least two studies found that rural residents were (at least partially) more physically active than urban residents. Rind and Jones compared the prevalence of physical activity among 354 English local authorities. ${ }^{20}$ Their study indicated that urban residents took less overall physical activity and had less energy expenditure from walking than their rural counterparts. Fan and colleagues evaluated urban-rural differences in physical activity based on a national survey data set. ${ }^{21}$ Their analysis suggested that the urban-rural difference in physical activity was conditional on the measurement of the intensity of the physical activity. Rural residents took more total physical activity while urban residents took more high-intensity physical activity. 
Recent studies have suggested that the urban-rural differences in physical activity might depend on individual demographic factors, activity type, and regional contexts. For example, an analysis by Carlson et al. found an urban-rural difference in weekly walking rate and that the difference varied by trip purpose and among the nine Census regions in the United States. ${ }^{22}$ However, in southern states, rural residents reported fewer weekly walking trips than urban residents regardless of trip purpose. McAndrews and colleagues used the 2009 NHTS data to compare cycling prevalence among ten levels of urban-rural commute areas. ${ }^{23}$ Their analysis found that, in general, urban residents rode bicycles more than rural residents. However, women and youth in rural, small, and low-density places reported more bicycle trips than their counterparts in urban places. A study of residents aged 40-65 in Brisbane, Australia showed that inner urban residents rode bicycles for transportation more than suburban and outer urban residents, but there were no differences in recreational cycling between them. ${ }^{24} \mathrm{~A}$ study of physical activity levels of youth in 20 counties in North Carolina found no differences between urban and rural boys but more physical activity by rural girls than urban and suburban girls. ${ }^{25}$

In summary, previous studies of the geographic patterns of physical activity have yielded mixed and even contradictory results. Researchers recognize the importance of understanding the varied correlates of physical activity in different geographic contexts. Extant research on physical activity in rural and non-metropolitan areas, however, is very limited and often restricted to isolated geographies. ${ }^{26}$ Research has consistently revealed that active travel modes of different purposes (e.g. utilitarian vs. leisure) demonstrates different trip characteristics (e.g. trip duration and length) and has different environmental correlates. ${ }^{27}$ Few studies, however, have analyzed the geographic patterns of active travel that were strictly for exercise. This study partially fills these gaps by analyzing the geographic disparities of physical activity, walking, and cycling at finer geographic scales in the entire nation. Unlike previous studies that relied on one-day travel diary data, this study used the 2017 NHTS in which respondents reported 7-day physical activity. The author adopted the zero-inflated poisson model and appropriately took into account the weighting variables in the model to make sure the model results are generalizable to the U.S. population. The author differentiate walk and bike trips that were strictly for exercise from walk and bike trips for other purposes.

Table 1. A Summary of Relevant Literature

\begin{tabular}{|c|c|c|c|c|c|}
\hline $\begin{array}{c}\text { Author } \\
\text { (year) }\end{array}$ & $\begin{array}{c}\text { Geographic } \\
\text { Pattern Analyzed }\end{array}$ & $\begin{array}{l}\text { Activity } \\
\text { Type }\end{array}$ & $\begin{array}{l}\text { Population } \\
\text { Group }\end{array}$ & $\begin{array}{l}\text { Data Source \& } \\
\text { Sample Size }\end{array}$ & $\begin{array}{l}\text { Geographic } \\
\text { Scope }\end{array}$ \\
\hline $\begin{array}{l}\text { Whitefield et } \\
\text { al. } \\
(2019)\end{array}$ & Urban-Rural & $\begin{array}{l}\text { Leisure \& } \\
\text { transportation } \\
\text { walking }\end{array}$ & $\begin{array}{l}\text { Adults } \\
\text { (aged 18+) }\end{array}$ & $\begin{array}{l}2015 \text { National Health } \\
\text { Interview Survey } \\
(\mathrm{N}=29,925)\end{array}$ & United States \\
\hline $\begin{array}{l}\text { Tribby \& Tharp } \\
\text { (2019) }\end{array}$ & $\begin{array}{l}\text { Urban areas of five } \\
\text { density levels and } \\
\text { rural areas of two } \\
\text { density levels }\end{array}$ & Bicycling & Age $5^{+}$ & $\begin{array}{l}2017 \mathrm{NHTS} \\
(\mathrm{N}=237,146)\end{array}$ & United States \\
\hline $\begin{array}{l}\text { Carlson et al. } \\
\text { (2018) }\end{array}$ & $\begin{array}{l}\text { Urban-Rural \& } \\
9 \text { Census divisions }\end{array}$ & $\begin{array}{l}\text { Leisure \& } \\
\text { transportation } \\
\text { walking }\end{array}$ & $\begin{array}{l}\text { Adults } \\
\text { (aged 18+) }\end{array}$ & $\begin{array}{l}2015 \text { National Health } \\
\text { Interview Survey } \\
(\mathrm{N}=29,925)\end{array}$ & United States \\
\hline
\end{tabular}




\begin{tabular}{|c|c|c|c|c|c|}
\hline $\begin{array}{c}\text { Author } \\
\text { (year) }\end{array}$ & $\begin{array}{c}\text { Geographic } \\
\text { Pattern Analyzed }\end{array}$ & $\begin{array}{l}\text { Activity } \\
\text { Type }\end{array}$ & $\begin{array}{l}\text { Population } \\
\text { Group }\end{array}$ & $\begin{array}{l}\text { Data Source \& } \\
\text { Sample Size }\end{array}$ & $\begin{array}{l}\text { Geographic } \\
\text { Scope }\end{array}$ \\
\hline $\begin{array}{l}\text { Sohn et al. } \\
(2017)\end{array}$ & 4 Census regions & $\begin{array}{l}\text { All types of } \\
\text { physical activity }\end{array}$ & $\begin{array}{l}\text { Men aged } \\
18+\end{array}$ & $\begin{array}{l}2000 \text { to } 2010 \text { National } \\
\text { Health Interview } \\
\text { Survey } \\
(\mathrm{N}=327,556)\end{array}$ & United States \\
\hline $\begin{array}{l}\text { Olsen et al. } \\
(2017)\end{array}$ & Urban-Rural & Active travel & Age 16+ & $\begin{array}{l}\text { 2012-13 Scottish } \\
\text { Household Survey } \\
\text { (39,585 journey } \\
\text { stages) }\end{array}$ & Scotland \\
\hline $\begin{array}{l}\text { McAndrews } \\
\text { et al. } \\
\text { (2017) }\end{array}$ & $\begin{array}{l}\text { Ten levels of } \\
\text { Rural-urban } \\
\text { commuting area }\end{array}$ & Bicycling & Age 5+ & $\begin{array}{l}2009 \mathrm{NHTS} \\
(\mathrm{N}=285,634)\end{array}$ & United States \\
\hline $\begin{array}{l}\text { Heesch et al. } \\
(2015)\end{array}$ & $\begin{array}{l}\text { Inner urban, } \\
\text { suburb, outer urban }\end{array}$ & $\begin{array}{l}\text { Transport \& } \\
\text { recreation } \\
\text { bicycling }\end{array}$ & Aged 40-65 & $\begin{array}{l}2007 \text { for HABITAT } \\
(\mathrm{N}=11,036)\end{array}$ & $\begin{array}{l}\text { Brisbane, } \\
\text { Australia }\end{array}$ \\
\hline $\begin{array}{l}\text { Short et al. } \\
(2014)\end{array}$ & $\begin{array}{l}\text { Regional cities vs. } \\
\text { regional areas }\end{array}$ & $\begin{array}{l}\text { All physical } \\
\text { activity lasted } \\
10+\text { minutes }\end{array}$ & $\begin{array}{l}\text { Members of } \\
\text { AHSS panel }\end{array}$ & $\begin{array}{l}\text { Data collected by } \\
\text { author } \\
(\mathrm{N}=756)\end{array}$ & Australia \\
\hline $\begin{array}{l}\text { Moore et al. } \\
(2014)\end{array}$ & Urban/suburb/rural & $\begin{array}{l}\text { Moderate-to- } \\
\text { vigorous } \\
\text { physical activity }\end{array}$ & $\begin{array}{l}\text { Youth }\left(4^{\text {th }}-8^{\text {th }}\right. \\
\text { grades })\end{array}$ & $\begin{array}{l}\text { Data collected by } \\
\text { author } \\
(\mathrm{N}=804)\end{array}$ & $\begin{array}{l}20 \text { North Carolina } \\
\text { counties }\end{array}$ \\
\hline $\begin{array}{l}\text { Fan et al. } \\
(2014)\end{array}$ & $\begin{array}{l}\text { Urban areas of } \\
\text { three levels and } \\
\text { rural areas of two } \\
\text { levels }\end{array}$ & $\begin{array}{l}\text { All physical } \\
\text { activity }\end{array}$ & Aged 20-75 & $\begin{array}{l}2003-2006 \text { Health and } \\
\text { Nutrition Examination } \\
\text { Survey } \\
(\mathrm{N}=5,056)\end{array}$ & United States \\
\hline $\begin{array}{l}\text { Moore et al. } \\
(2013)\end{array}$ & Urban-Rural & $\begin{array}{l}\text { Moderate-to- } \\
\text { vigorous } \\
\text { physical activity } \\
\text { (MVPA) }\end{array}$ & $\begin{array}{l}\text { Youth in } \\
\text { middle school }\end{array}$ & $\begin{array}{l}\text { Data collected } \\
\text { by autuhor via } \\
\text { accelerometer } \\
(\mathrm{N}=284)\end{array}$ & $\begin{array}{l}3 \text { middle schools } \\
\text { in US south }\end{array}$ \\
\hline $\begin{array}{l}\text { Cleland et al. } \\
(2012)\end{array}$ & $\begin{array}{l}\text { Urban-Rural } \\
\text { (socioeconomically } \\
\text { disadvantaged ) }\end{array}$ & $\begin{array}{l}\text { Leisure-time \& } \\
\text { transport-related }\end{array}$ & $\begin{array}{l}\text { Women } \\
18-45 \text { years } \\
\text { old }\end{array}$ & $\begin{array}{l}\text { Data collected by } \\
\text { author } \\
(\mathrm{N}=3,669)\end{array}$ & $\begin{array}{l}40 \text { urban and } \\
40 \text { rural areas in } \\
\text { Australia }\end{array}$ \\
\hline $\begin{array}{l}\text { Rind \& Jones } \\
(2011)\end{array}$ & $\begin{array}{l}354 \text { English local } \\
\text { authorities }\end{array}$ & $\begin{array}{l}\text { Recreational } \\
\text { physical activity }\end{array}$ & Age 16+ & $\begin{array}{l}2006 \text { APS } \\
(N=363,724)\end{array}$ & England \\
\hline $\begin{array}{l}\text { Duncan et al. } \\
\text { (2009) }\end{array}$ & $\begin{array}{l}\text { Metro vs. non- } \\
\text { metro }\end{array}$ & $\begin{array}{l}\text { Recreational \& } \\
\text { transportation } \\
\text { walking }\end{array}$ & Adults & $\begin{array}{l}\text { CATI survey } \\
(\mathrm{N}=1,208)\end{array}$ & $\begin{array}{l}\text { Queensland, } \\
\text { Australia }\end{array}$ \\
\hline $\begin{array}{l}\text { Nelson et al. } \\
2006\end{array}$ & $\begin{array}{l}6 \text { types of } \\
\text { neighborhood } \\
\text { clusters }\end{array}$ & $\begin{array}{l}\text { General physical } \\
\text { activity }\end{array}$ & $\begin{array}{l}\text { Adolescent } \\
(7-12 \\
\text { grades })\end{array}$ & $\begin{array}{l}1994-1995 \mathrm{NLSAH} \\
(\mathrm{N}=20,745)\end{array}$ & United States \\
\hline $\begin{array}{l}\text { Badland \& } \\
\text { Schofield } \\
\text { (2006) }\end{array}$ & $\begin{array}{l}\text { Town size of } 4 \\
\text { levels }\end{array}$ & $\begin{array}{l}\text { walking \& } \\
\text { other physical } \\
\text { activities }\end{array}$ & Age $16+$ & $\begin{array}{l}\text { Data collected by } \\
\text { author } \\
(\mathrm{N}=7,916)\end{array}$ & New Zealand \\
\hline $\begin{array}{l}\text { Martin et al. } \\
(2005)\end{array}$ & $\begin{array}{l}\text { Urban-Rural \& } \\
4 \text { Census regions }\end{array}$ & $\begin{array}{l}\text { General physical } \\
\text { activity }\end{array}$ & $\begin{array}{l}\text { Adults } \\
\text { (aged 18+) }\end{array}$ & $\begin{array}{l}2000 \text { Behavioral Risk } \\
\text { Factor Surveillance } \\
\text { System }(N=126,824)\end{array}$ & United States \\
\hline $\begin{array}{l}\text { Parks et al. } \\
(2003)\end{array}$ & Urban/suburb/rural & $\begin{array}{l}\text { General physical } \\
\text { activity }\end{array}$ & $\begin{array}{l}\text { Low-income } \\
\text { aged } 18+\end{array}$ & $\begin{array}{l}\text { Phone survey by } \\
\text { author } \\
(\mathrm{N}=1,818)\end{array}$ & United States \\
\hline $\begin{array}{l}\text { Wilcox et al. } \\
(2000)\end{array}$ & Urban-Rural & $\begin{array}{l}\text { Leisure time } \\
\text { physical activity }\end{array}$ & Women 40+ & $\begin{array}{l}\text { US Women's } \\
\text { Determinants Study } \\
(\mathrm{N}=1242 \text { rural \& } 1096 \\
\text { urban) }\end{array}$ & United States \\
\hline
\end{tabular}




\section{DATA AND METHODS}

\section{DATA}

This study utilized the 2017 National Household Travel Survey (NHTS) data set. Sponsored by the Federal Highway Administration, the NHTS collected the nation's information about travel by civilian residents in all 50 states and the District of Columbia. The main survey was conducted from March 2016 through May 2017. The previous two NHTSs were in 2001 and 2009. The survey covers travel behavior of nearly all travel modes for all purposes. The 2017 NHTS included 13 'add-on' partners (states and Metropolitan Planning Organizations). The data set included a national sample of 26,000 households and 103,112 additional samples from the 13 'add-on' partners. The entire data set included information about 264,234 respondents aged five and older. The 2017 NHTS added a few new questions to probe how physically active American people were in a typical week, how many walk and bike trips they took in the past seven days, and how many of these walk and bike trips were strictly for exercise, as well as the barriers that prevented them from walking and biking more. ${ }^{28}$

The public version of the 2017 NHTS data set contains variables that describe the sociodemographic characteristics of each respondent such as age, sex, education, employment status, and household income. The researchers obtained access to the restricted version of the 2017 NHTS data set, which contains the home addresses of all respondents at the Census block group level. The data enabled the researchers to measure the social and physical environment of each respondent's neighborhood by linking the data with the 20122016 American Community Survey (ACS) data and the 2016 Census Longitudinal EmployerHousehold Dynamics (LEHD) data.

The 2017 NHTS asked two questions to understand the factors that kept walkers and cyclists from walking and biking more. These two questions were asked of self-reporters who took at least one walk or bike trip in the past seven days. The respondent could choose one or more from six potential barriers. Three of them are related to infrastructure: no nearby paths or trails, no nearby parks, and no sidewalks or sidewalks are in poor condition. The other three focus on safety: street crossings are unsafe, heavy traffic with too many cars, and not enough lighting at night.

The 2017 NHTS applied complex sampling strategies to make sure the data reflected the U.S. population as a whole. Accordingly, the applied weights provided in the data set in the descriptive and modeling analyses to correct for non-representativeness of the original raw sample. Specifically, the researchers- utilized open-source software R's "Survey" package ${ }^{29}$ to take into account the sampling strategies in the descriptive and modeling analyses. The "Survey" package utilized the sampling weight and 98 replicate weights provided in the 2017 NHTS data set to calculate unbiased standard errors.

\section{MEASUREMENT}

The descriptive statistics of all the outcome and explanatory variables are presented in Table 2. 


\section{Five Outcome Variables}

The analysis focused on five outcome variables that were developed based on respondents' response to the two survey questions regarding residents' physical activity. The first is a three-level ordinal variable that describe each person's level of physical activity: no or never, light or moderate, and vigorous. The other four outcome variables are count variables. They represent each person's active travel in the past seven days: 1) the number of walk trips strictly for exercise (weekly exercise walk trip rate), 2) the number of walk trips not for exercise (weekly non-exercise walk trip rate), 3) the number of bike trips strictly for exercise (weekly exercise bike trip rate), and 4) the number of bike trips not for exercise (weekly nonexercise bike trip rate). When respondents reported not taking any walk/bike trips in the past seven days, their numbers of walk/bike trips strictly for exercise were coded as zero.

\section{Key Explanatory Variables}

To analyze the geographic patterns of the five outcome variables, the researchers first categorized respondents into three general groups: large metropolitan areas with more than a half million population, small metropolitan areas with less than a half million population, and non-metropolitan areas.

The researchers further divided large metropolitan areas into four intra-metropolitan locations: downtown, inner-ring suburb, mid-ring suburb, and outer-ring suburb. The researchers defined downtown and suburban neighborhoods based on their distances to the central business districts (CBDs). The researchers used different radii of inner cities among metropolitan areas of different sizes: one mile for metropolitan areas with a half to one million population, two miles for metropolitan areas with a population of one to two millions, and three miles for metropolitan areas with a population of more than two million. The research team identified the suburban ring in which a neighborhood is located based on the ratio between its distance to the CBD and the weighted mean distance of all neighborhoods to the CBD in that metropolitan area. Specifically, an inner-ring suburb consists of neighborhoods that are outside of downtown but within half of the weighted mean distance to the CBD; a mid-ring suburb includes neighborhoods that lie at the distances of $0.5-1.5$ of the weighted mean distance to the CBD; and an outer-ring suburb consists of neighborhoods that are at least 1.5 of the weighted mean distance to the CBD. 
Table 2. Descriptive Statistics of Variables

\begin{tabular}{|c|c|c|c|}
\hline & $\begin{array}{c}\text { Percent (\%) } \\
\text { (weighted) }\end{array}$ & $\begin{array}{c}\text { Mean } \\
\text { (weighted) }\end{array}$ & $\begin{array}{c}\text { Sample Size } \\
\text { (unweighted) }\end{array}$ \\
\hline Physical Activity: & & & 263611 \\
\hline none or rare & 12.60 & & \\
\hline light or moderate & 60.63 & & \\
\hline vigorous & 26.62 & & \\
\hline Weekly Rate of Walk Trips for Exercise & & 2.04 & 263,048 \\
\hline Weekly Rate of Walk Trips not for Exercise & & 3.56 & 263,409 \\
\hline Weekly Rate of Bike Trips for Exercise & & 0.21 & 264,090 \\
\hline Weekly Rate of Bike Trips not for Exercise & & 0.25 & 264,018 \\
\hline Sex: & & & 263,778 \\
\hline male & 49.07 & & -- \\
\hline female & 50.93 & & -- \\
\hline Age: & & & 263,525 \\
\hline $5-12$ & 10.99 & & \\
\hline $13-17$ & 6.83 & & \\
\hline $18-24$ & 10.37 & & \\
\hline $25-34$ & 14.07 & & \\
\hline $35-44$ & 14.03 & & \\
\hline $45-54$ & 13.43 & & \\
\hline $55-64$ & 14.46 & & \\
\hline $65+$ & 15.82 & & \\
\hline Household Income: & & & 256,094 \\
\hline$<\$ 25 k$ & 19.46 & & \\
\hline$\$ 25 k-\$ 50 k$ & 20.52 & & \\
\hline$\$ 50 k-\$ 75$ & 16.60 & & \\
\hline$\$ 75-\$ 100 k$ & 13.21 & & \\
\hline$>\$ 100 \mathrm{k}$ & 30.21 & & \\
\hline Education: & & & 263,791 \\
\hline n.a. $($ age $<16)$ & 12.31 & & \\
\hline below high school & 10.46 & & \\
\hline high school & 18.92 & & \\
\hline some college education & 25.05 & & \\
\hline bachelor & 18.44 & & \\
\hline graduate degree & 14.83 & & \\
\hline Race/ethnicity: & & & 263,140 \\
\hline White & 61.50 & & \\
\hline Black & 12.04 & & \\
\hline Asian & 5.21 & & \\
\hline Hispanic & 17.25 & & \\
\hline Other & 4.01 & & \\
\hline
\end{tabular}




\begin{tabular}{|c|c|c|c|}
\hline & $\begin{array}{c}\text { Percent (\%) } \\
\text { (weighted) }\end{array}$ & $\begin{array}{c}\text { Mean } \\
\text { (weighted) }\end{array}$ & $\begin{array}{r}\text { Sample Size } \\
\text { (unweighted) }\end{array}$ \\
\hline Employment Status: & & & 263,984 \\
\hline working & 44.93 & & \\
\hline temporarily not working & 2.48 & & \\
\hline look for work/unemployed & 3.53 & & \\
\hline homemaker & 6.20 & & \\
\hline going to school & 6.51 & & \\
\hline retired & 15.27 & & \\
\hline something else & 6.00 & & \\
\hline n.a. $($ age $<16)$ & 15.08 & & \\
\hline Homeownership: & & & 263958 \\
\hline own & 66.01 & & \\
\hline rent & 32.94 & & \\
\hline other arrangement & 1.06 & & \\
\hline Proxy: & & & 264,018 \\
\hline self-report & 65.72 & & \\
\hline proxy-report & 34.28 & & \\
\hline Vehicle Ownership (cars per driver in household) & & 1.05 & 264,018 \\
\hline Population Density (100,000 per squared miles) & & 0.07 & 264,018 \\
\hline Employment Density (100,000 per squared miles) & & 0.02 & 264,089 \\
\hline Mixed Land Use: & & & 263,086 \\
\hline low & 81.36 & & \\
\hline medium & 9.70 & & \\
\hline high & 8.94 & & \\
\hline Median Household Income $(\$ 10,000)$ & & 6.60 & 260,936 \\
\hline Poverty Rate & & 0.14 & 264,001 \\
\hline Share of White & & 0.64 & 264,013 \\
\hline Share of Black & & 0.12 & 264,013 \\
\hline Share of Hispanic & & 0.16 & 264,013 \\
\hline Season: & & & 264,018 \\
\hline spring & 24.90 & & \\
\hline summer & 25.24 & & \\
\hline fall & 25.13 & & \\
\hline winter & 24.72 & & \\
\hline Urban size: & & & 264,018 \\
\hline $50 \mathrm{k}-200 \mathrm{k}$ & 9.52 & & \\
\hline $200 k-500 k$ & 10.05 & & \\
\hline $500 \mathrm{k}-1$ million & 8.88 & & \\
\hline $1+$ million without heavy rail & 20.23 & & \\
\hline $1+$ million with heavy rail & 24.11 & & \\
\hline not in an urbanized area & 27.21 & & \\
\hline
\end{tabular}




\begin{tabular}{|c|c|c|c|}
\hline & $\begin{array}{c}\text { Percent (\%) } \\
\text { (weighted) }\end{array}$ & $\begin{array}{c}\text { Mean } \\
\text { (weighted) }\end{array}$ & $\begin{array}{c}\text { Sample Size } \\
\text { (unweighted) }\end{array}$ \\
\hline Intra- \& Inter-metro Location: & & & 263,895 \\
\hline large metropolitan: downtown & 3.36 & & \\
\hline large metropolitan: inner-suburb & 14.48 & & \\
\hline large metropolitan: mid-suburb & 34.62 & & \\
\hline large metropolitan: outer-suburb & 15.15 & & \\
\hline small metropolitan: urban & 13.77 & & \\
\hline small metropolitan: rural & 4.13 & & \\
\hline not in a metropolitan area: urban & 6.16 & & \\
\hline not in a metropolitan area: rural & 8.26 & & \\
\hline Census Division: & & & 264,018 \\
\hline New England & 4.62 & & \\
\hline East North Central & 14.59 & & \\
\hline East South Central & 5.88 & & \\
\hline Mid-Atlantic & 12.98 & & \\
\hline Mountain & 7.29 & & \\
\hline Pacific & 16.30 & & \\
\hline South Atlantic & 19.76 & & \\
\hline West North Central & 6.55 & & \\
\hline West South Central & 12.03 & & \\
\hline
\end{tabular}

For respondents in small metropolitan areas, the researchers divided them into two groups (urban vs. rural) based on urban area classification in the 2014 TIGER/Line shapefile, which are extracts of selected geographic information from the U.S. Census Bureau's database and include the boundaries of geographic areas and features in the United States. Similarly, the researchers divided non-metropolitan areas into urban and rural parts. The key geographic variable represents eight geographic locations:

1. Large metropolitan area: inner city

2. Large metropolitan area: inner-ring suburb

3. Large metropolitan area: mid-ring suburb

4. Large metropolitan area: outer-ring suburb

5. Small metropolitan area: urban

6. Small metropolitan area: rural

7. Non-metropolitan area: urban

8. Non-metropolitan area: rural 


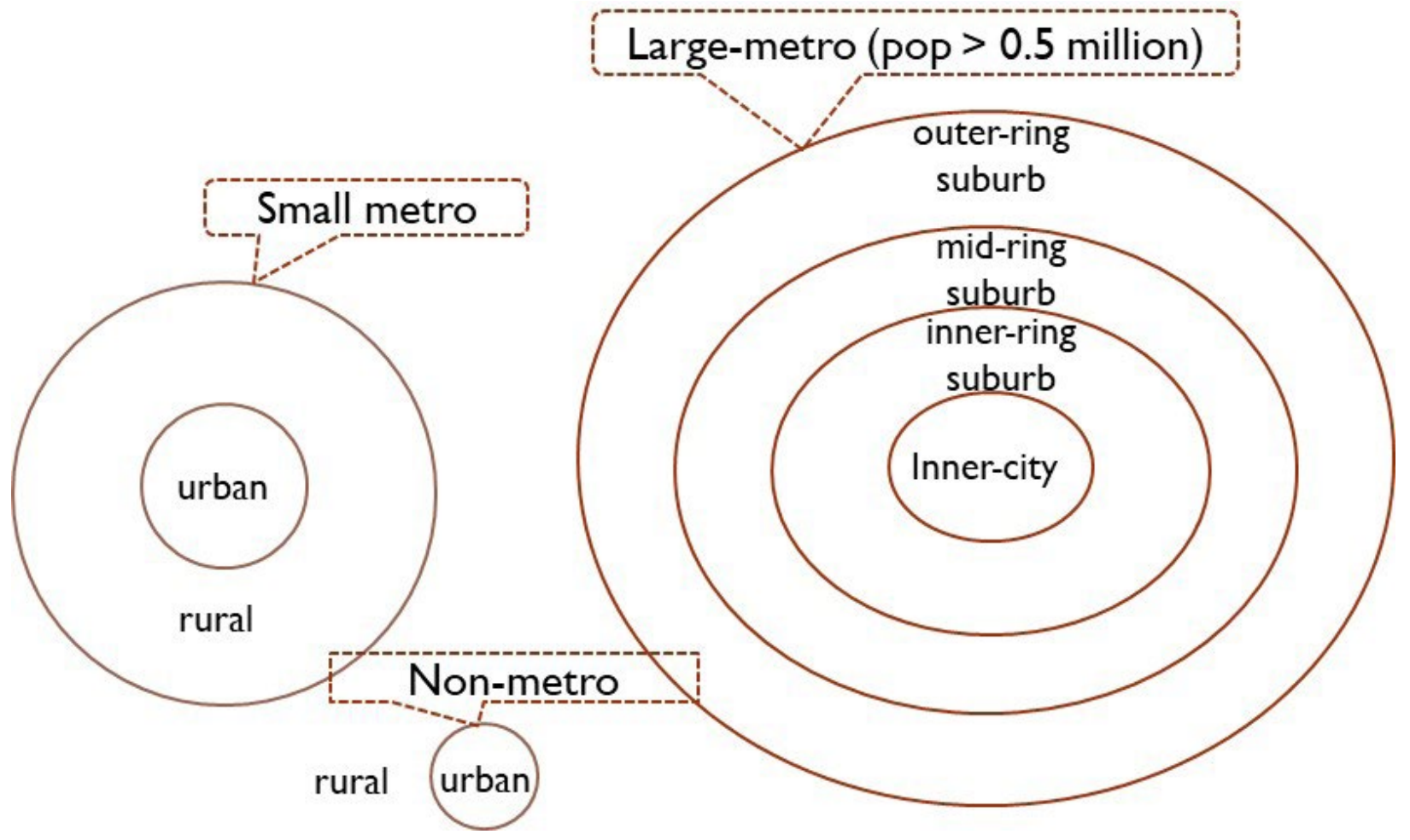

Figure 1. Eight Geographic Locations

\section{Control Variables}

The researchers developed a series of control variables to measure individual-level sociodemographic characteristics and neighborhood-level social and physical environments. Specifically, individual-level variables describe each person's gender, age, race/ethnicity, income, education, employment status, homeownership, and vehicle ownership. Census block groups were used to represent neighborhoods. The researchers calculated neighborhood population and employment densities based on population, employment, and land area in each block group. Mixed land use was measured in each neighborhood by using a ratio between the number of jobs and population, then further categorizing neighborhoods into three groups based on the ratio: low, medium, and high. The researchers used five variables to describe the social environment of each neighborhood: median household income, poverty rate, and the shares of White, Black, and Hispanic population.

In addition, the researchers used a variable to differentiate self-reporters from proxy reporters. The researchers had a variable to represent the season in which the survey took place. The researchers included a categorical variable to represent urban areas of different population sizes and another categorical variable to represent the nine Census divisions.

\section{MODELING TECHNIQUES}

The researchers estimated five sets of models for the five outcome variables. The researchers run ordered logistic regression models to decide the associations between physical activity level and geographic location after controlling for individual-level and neighborhood-level variables. The researchers chose the ordered logistic regression method because the "distances" between the three levels of physical activity (never/rare, light/moderate, and 
vigorous) may not be equal.

The researchers run zero-inflated Poisson models to identify significant geographic, neighborhood, and individual variables that predict the weekly rates of walk and bike trips for exercise and non-exercise purposes. The researchers chose the zero-inflated Poisson model because the data had an excess of zero counts. For example, $93 \%$ of respondents reported zero bike trips strictly for exercise, and $94 \%$ of them reported zero bike trips for non-exercise purposes. Ordinary count models might not be appropriate when there is an excess of zero counts.

A zero-inflated Poisson regression jointly estimates two sub-models: a logit model and a Poisson model. The zero-inflated Poisson model considers two different processes that could lead a respondent to report zero walk or bike trips in the past seven days. One respondent could usually take some walk or bike trips but happened not to take any in the seven days before participating in the survey. Another respondent did not take any walk or bike trips because she did not have any interest or did not have the capability to do so (e.g. medical conditions or not owning a bicycle). Both of them reported zero trips, but they arrived at the same outcome through two different processes. The second respondent is considered a "certain zero." The logit model predicts whether one respondent would be in this "certain zero" group. The Poisson model predicts the number of walk or bike trips for respondents who are not in the certain-zero group.

In summary, the researchers uses four major groups of variables to predict an individual resident's physical activity: the geographic location that the resident lives in, the residents' personal and family demographics, and the social and physical environments of the neighborhood in which the resident lives. Two modeling techniques were selected based on the statistical attributes of the outcome variables. Ordered logistic regression is used when the outcome variable represents the three levels of physical activity that a resident could have. Zero-inflated Poisson model was used when outcome variable represent the number of walking/biking trips, which contain a lot of zeros. 


\section{RESULTS AND FINDINGS}

\section{DESCRIPTIVE ANALYSIS}

The researchers demonstrated the geographic variation of the five outcome variables (physical activity, weekly rate of exercise walk trips, weekly rate of non-exercise walk trips, weekly rate of exercise bike trips, and weekly non-exercise bike trips) among the eight geographic locations in Figure $2(\mathrm{a}-\mathrm{c})$. The researchers also run t-tests to decide whether a difference between two locations was statistically significant.

Figure $2 a$ suggests that there is only slight variation in physical activity between residents in the eight geographic locations. The t-tests confirm that residents in inner cities of large metropolitan areas took significantly more vigorous-intensity physical activity but less lightand moderate-intensity activity than those in other seven locations. The differences between seven other locations outside of inner cities are not statistically significant.

There are very slight differences in the weekly rates of exercise walk trips between the eight geographic locations, as shown in Figure $2 \mathrm{~b}$. The t-tests show that compared to that in the mid-ring suburbs, the weekly rate of exercise walk trips is significantly higher in inner cities of large metropolitan areas, the urban parts of small metropolitan areas, and the rural parts of non-metropolitan areas. The magnitude of the differences, however, is quite small.

There is much more variation in the weekly rates of non-exercise walk trips between the eight geographic locations. Residents in inner cities of large metropolitan areas took almost eight non-exercise walks per week, which is more than double what inner-ring and outer-ring suburbanites took (about three per week). Compared with mid-ring suburbanites, the weekly rates of non-exercise walks are significantly larger for inner-ring suburbanites (4.4 per week) and rural residents in small metropolitan areas (3.8 times per week) and non-metropolitan areas (4.3 times per week). These seem to suggest that residents took more non-exercise walks when they lived in areas with the highest and lowest levels of urbanization: the inner cities of large metropolitan areas and the rural areas. Suburbanites, particularly mid-ring and outer-ring suburbanites, took the least number of non-exercise walks.

Similarly, mid-ring and outer-ring suburbanites reported the least number of bike trips for non-exercise purposes (Figure 2c). Residents in inner cities of large metropolitan areas took the largest number of non-exercise bike trips. Compared with mid-ring suburbanites, innerring suburbanites and urban residents in small metropolitan areas also took significantly more non-exercise bike trips. There are no significant differences in the weekly rates of exercise bike trips between the eight geographic locations. 
a) percent of residents by levelof physical activity

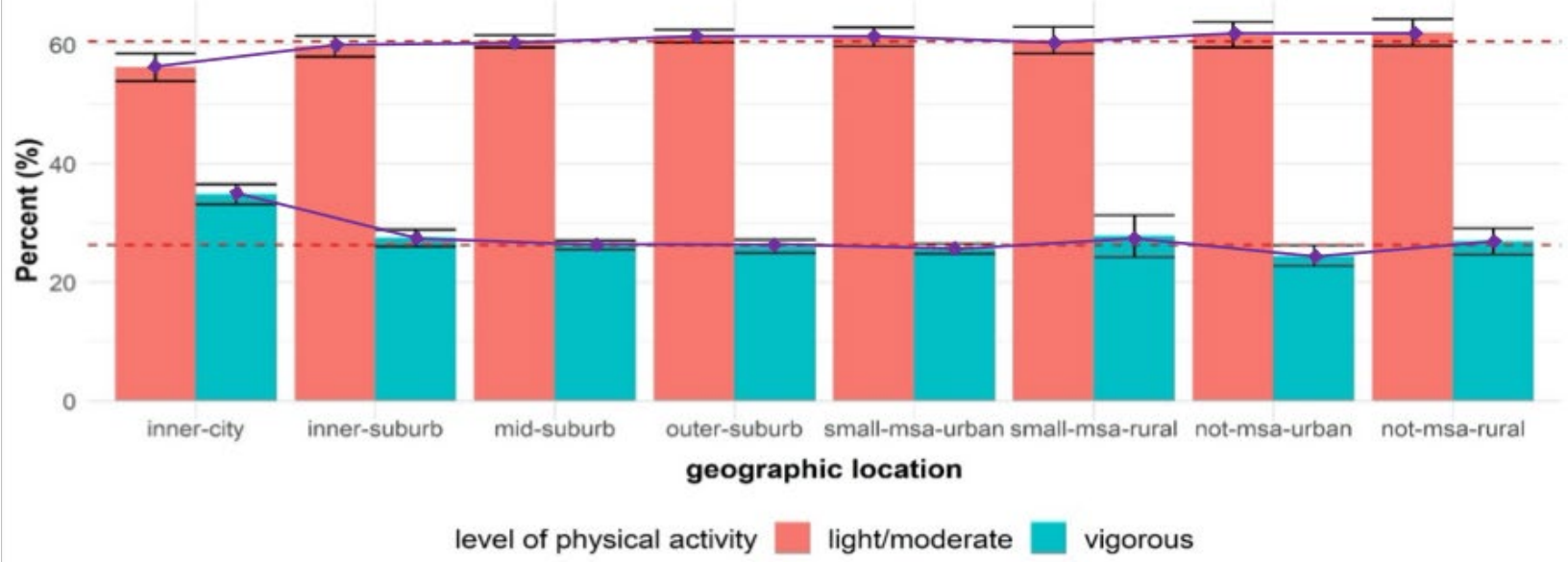

b) weekly walk rate

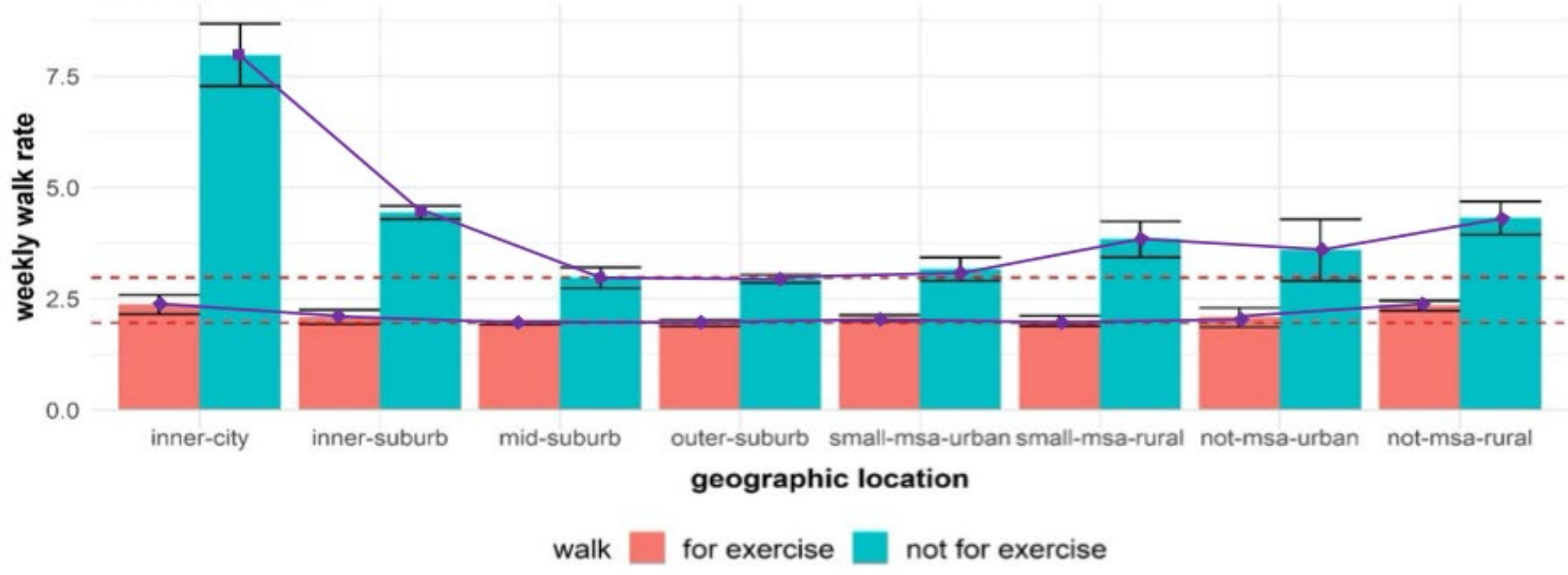

c) weekly bıke rate

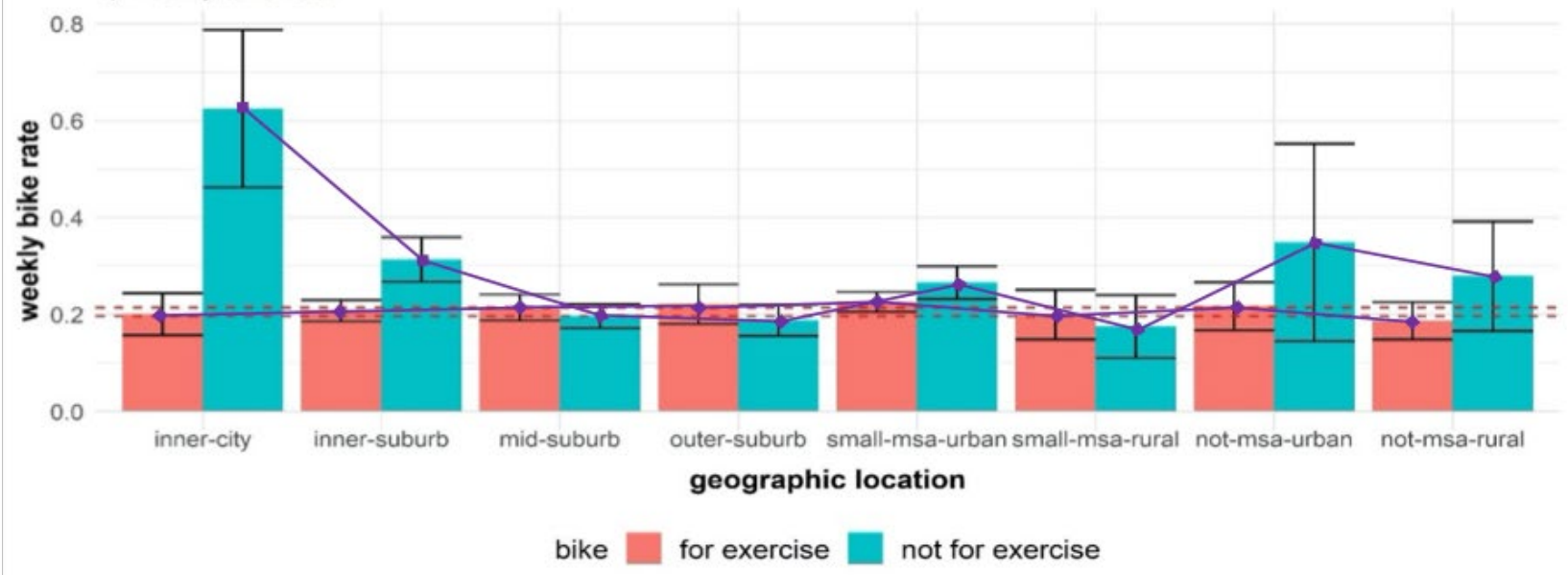

Figure 2. Geographic Variation of Physical Activity

\section{MODELING ANALYSIS}

For each of the five outcome variables, two models were run. One base model included all the explanatory variables but not the neighborhood-level variables. This is to test whether the geographic patterns of physical activity and active travel hold after controlling for individual 
characteristics. The full model included all the explanatory variables presented in Table 3. This is to test whether the geographic patterns hold after controlling for both individual- and neighborhood-level variables. The following discussions are based on the two ordered logistic regression models and the eight zero-inflated Poisson models with each Poisson model containing two sub-models. Due to space limitation, in Table 2, the researchers reported only the results of the full models that included all the explanatory variables.

It is important to note that the results of the geographic variable are largely consistent between the base models and the full models. This suggests that the geographic pattern of the five outcome variables cannot be explained by neighborhood characteristics. If a geographic variable yielded two coefficients of different significance or sign (positive/negative) in the base and full models, the researchers noted them in the following discussions. It is also worth noting that one variable may yield two coefficients of opposite signs in the two sub-models of a zero-inflated Poisson model. This is because the logit model (certain-zero model) predicts whether a person is certain to report zero trips, while the Poisson model (count model) predicts how many trips one takes in a week if he/she is not in the certain group.

The model results show that residents were more physically active when they lived in inner cities and inner-suburbs of large metropolitan areas or in the rural parts of non-metropolitan areas, after controlling for other variables. The levels of physical activity were similar among residents in the other five geographic locations. The relationship between physical activity level and urbanization demonstrates a flat U-shape. Residents were more physically active when they lived in areas from the two ends of the urbanization spectrum: the inner parts of large metropolitan areas and the rural parts of non-metropolitan areas.

There were no significant differences among the residents in eight geographic locations in terms of their tendency to certainly report zero weekly walk trips that are strictly for exercise. For residents that were not in the certain-zero group, they tended to take a greater number of exercise walks if they lived in the downtown areas of large metropolitan areas, the urban parts of small metropolitan areas, and the rural parts of non-metropolitan areas. The difference between downtown residents and mid-ring suburbanites became statistically insignificant after neighborhood-level variables were added to the model, suggesting that the difference is likely due to the variation of neighborhood environment. However, urban residents in small metropolitan areas and rural residents in non-metropolitan areas remained associated with a greater number of exercise walks than mid-ring suburbanites after controlling for neighborhood-level variables.

Residents were more likely to take non-exercise walks and tended to take a greater number of non-exercise walks when they lived in areas from the two ends of the urbanization spectrum: inner cities and inner-suburbs of large metropolitan areas and the rural parts of non-metropolitan areas. This is largely consistent with the geographic patterns of physical activity.

Geographic locations were associated with the probability that one was certain to report zero bike trips, but they were not correlated with the number of bike trips. Compared with mid-ring suburbanites, inner-city residents and urban residents in small metropolitan areas were less likely to be in the certain-zero group, and rural residents in non-metropolitan areas 
were more likely to be in the certain-zero group. The difference between inner-city residents and mid-ring suburbanites, however, became statistically insignificant after controlling for neighborhood-level variables. 
Table 3. Results of the Full Models

\begin{tabular}{|c|c|c|c|c|c|c|c|c|c|}
\hline & \multirow{3}{*}{$\begin{array}{c}\text { DV = 3-level } \\
\text { Physical Activity } \\
\text { Ordered } \\
\text { Logistic Model } \\
\text { Coef. } \\
\text { (z-value) }\end{array}$} & \multicolumn{2}{|c|}{$\begin{array}{c}\text { DV=Weekly Exercise } \\
\text { Walk Trip Rate }\end{array}$} & \multicolumn{2}{|c|}{$\begin{array}{c}\text { DV=Weekly Non-exercise } \\
\text { Walk Trip Rate }\end{array}$} & \multicolumn{2}{|c|}{$\begin{array}{c}\text { DV=Weekly Exercise } \\
\text { Bike Trip Rate }\end{array}$} & \multicolumn{2}{|c|}{$\begin{array}{c}\text { DV=Weekly Non-exercise } \\
\text { Bike Trip Rate }\end{array}$} \\
\hline & & $\begin{array}{l}\text { Zero } \\
\text { Model }\end{array}$ & $\begin{array}{l}\text { Count } \\
\text { Model }\end{array}$ & $\begin{array}{l}\text { Zero } \\
\text { Model }\end{array}$ & $\begin{array}{l}\text { Count } \\
\text { Model }\end{array}$ & $\begin{array}{l}\text { Zero } \\
\text { Model }\end{array}$ & $\begin{array}{l}\text { Count } \\
\text { Model }\end{array}$ & $\begin{array}{l}\text { Zero } \\
\text { Model }\end{array}$ & $\begin{array}{l}\text { Count } \\
\text { Model }\end{array}$ \\
\hline & & $\begin{array}{c}\text { Coef. } \\
\text { (z-value) }\end{array}$ & $\begin{array}{c}\text { Coef. } \\
\text { (z-value) }\end{array}$ & $\begin{array}{c}\text { Coef. } \\
\text { (z-value) }\end{array}$ & $\begin{array}{c}\text { Coef. } \\
\text { (z-value) }\end{array}$ & $\begin{array}{c}\text { Coef. } \\
\text { (z-value) }\end{array}$ & $\begin{array}{c}\text { Coef. } \\
\text { (z-value) }\end{array}$ & $\begin{array}{c}\text { Coef. } \\
\text { (z-value) }\end{array}$ & $\begin{array}{c}\text { Coef. } \\
\text { (z-value) }\end{array}$ \\
\hline \multicolumn{10}{|l|}{ Geographic Location } \\
\hline $\begin{array}{l}\text { Downtown } \\
\text { Large MSA }\end{array}$ & $\begin{array}{l}0.413^{* *} \\
(7.447)\end{array}$ & $\begin{array}{l}-0.047 \\
(-1.015)\end{array}$ & $\begin{array}{c}0.069 \\
(1.567)\end{array}$ & $\begin{array}{l}-0.730^{* *} \\
(-11.057)\end{array}$ & $\begin{array}{l}0.172^{* *} \\
(3.172)\end{array}$ & $\begin{array}{l}-0.208 \\
(-1.776)\end{array}$ & $\begin{array}{l}-0.242 \\
(-1.761)\end{array}$ & $\begin{array}{l}-0.899 * * \\
(-5.974)\end{array}$ & $\begin{array}{c}0.151 \\
(1.331)\end{array}$ \\
\hline $\begin{array}{l}\text { Inner-suburb } \\
\text { Large MSA }\end{array}$ & $\begin{array}{l}0.156^{* *} \\
(4.359)\end{array}$ & $\begin{array}{l}-0.020 \\
(-0.676)\end{array}$ & $\begin{array}{c}0.039 \\
(1.252)\end{array}$ & $\begin{array}{l}-0.258^{* *} \\
(-6.209)\end{array}$ & $\begin{array}{c}0.080 \\
(1.490)\end{array}$ & $\begin{array}{l}-0.152 \\
(-1.434)\end{array}$ & $\begin{array}{l}-0.227 \\
(-1.509)\end{array}$ & $\begin{array}{l}-0.305^{\star *} \\
(-3.288)\end{array}$ & $\begin{array}{c}0.092 \\
(0.854)\end{array}$ \\
\hline $\begin{array}{l}\text { Mid-suburb } \\
\text { Large MSA } \\
\text { (reference) }\end{array}$ & -- & -- & -- & -- & -- & -- & -- & -- & -- \\
\hline $\begin{array}{l}\text { Outer-suburb } \\
\text { Large MSA }\end{array}$ & $\begin{array}{c}-0.024 \\
(-0.632)\end{array}$ & $\begin{array}{c}0.016 \\
(0.562)\end{array}$ & $\begin{array}{c}0.006 \\
(0.370)\end{array}$ & $\begin{array}{c}0.024 \\
(0.582)\end{array}$ & $\begin{array}{c}0.010 \\
(0.343)\end{array}$ & $\begin{array}{l}-0.015 \\
(-0.222)\end{array}$ & $\begin{array}{l}0.002 \\
(0.12)\end{array}$ & $\begin{array}{c}0.039 \\
(0.331)\end{array}$ & $\begin{array}{c}0.050 \\
(0.937)\end{array}$ \\
\hline $\begin{array}{l}\text { Urban } \\
\text { Small MSA }\end{array}$ & $\begin{array}{c}0.046 \\
(1.012)\end{array}$ & $\begin{array}{c}-0.087 \\
(-1.528)\end{array}$ & $\begin{array}{l}0.044^{*} \\
(2.330)\end{array}$ & $\begin{array}{c}-0.023 \\
(-0.306)\end{array}$ & $\begin{array}{c}0.028 \\
(0.706)\end{array}$ & $\begin{array}{l}-0.124^{* *} \\
(-2.950)\end{array}$ & $\begin{array}{c}-0.096 \\
(-1.157)\end{array}$ & $\begin{array}{l}-0.278^{* *} \\
(-2.605)\end{array}$ & $\begin{array}{c}0.045 \\
(0.416)\end{array}$ \\
\hline $\begin{array}{l}\text { Rural } \\
\text { Small MSA }\end{array}$ & $\begin{array}{c}0.050 \\
(0.655)\end{array}$ & $\begin{array}{c}0.084 \\
(1.745)\end{array}$ & $\begin{array}{c}0.042 \\
(1.694)\end{array}$ & $\begin{array}{c}-0.155 \\
(-1.824)\end{array}$ & $\begin{array}{l}0.171^{* *} \\
(2.708)\end{array}$ & $\begin{array}{c}0.163 \\
(1.692)\end{array}$ & $\begin{array}{c}0.081 \\
(0.573)\end{array}$ & $\begin{array}{c}0.005 \\
(0.031)\end{array}$ & $\begin{array}{c}0.041 \\
(0.200)\end{array}$ \\
\hline $\begin{array}{l}\text { Urban } \\
\text { Not in a MSA }\end{array}$ & $\begin{array}{c}0.029 \\
(0.423)\end{array}$ & $\begin{array}{c}0.040 \\
(0.657)\end{array}$ & $\begin{array}{c}0.084 \\
(1.589)\end{array}$ & $\begin{array}{c}0.110 \\
(1.800)\end{array}$ & $\begin{array}{c}0.108 \\
(1.231)\end{array}$ & $\begin{array}{c}0.061 \\
(0.409)\end{array}$ & $\begin{array}{c}0.033 \\
(0.193)\end{array}$ & $\begin{array}{l}-0.169 \\
(-0.871)\end{array}$ & $\begin{array}{c}0.446 \\
(1.331)\end{array}$ \\
\hline $\begin{array}{l}\text { Rural } \\
\text { Not in a MSA }\end{array}$ & $\begin{array}{l}0.154^{*} \\
(2.444)\end{array}$ & $\begin{array}{c}0.005 \\
(0.090)\end{array}$ & $\begin{array}{l}0.209^{* *} \\
(5.599)\end{array}$ & $\begin{array}{l}-0.180^{*} \\
(-2.159)\end{array}$ & $\begin{array}{l}0.249^{* *} \\
(3.218)\end{array}$ & $\begin{array}{l}0.255^{\star *} \\
(2.597)\end{array}$ & $\begin{array}{c}0.138 \\
(0.707)\end{array}$ & $\begin{array}{c}-0.263 \\
(-1.639)\end{array}$ & $\begin{array}{c}0.285 \\
(1.439)\end{array}$ \\
\hline \multicolumn{10}{|l|}{$\begin{array}{l}\text { Neighborhood } \\
\text { Characteristics }\end{array}$} \\
\hline Population Density & $\begin{array}{l}0.161^{*} \\
(2.140)\end{array}$ & $\begin{array}{c}0.041 \\
(0.661)\end{array}$ & $\begin{array}{c}0.091 \\
(1.380)\end{array}$ & $\begin{array}{l}-1.906^{* *} \\
(-13.911)\end{array}$ & $\begin{array}{l}0.282^{* *} \\
(6.961)\end{array}$ & $\begin{array}{l}-0.407^{\star *} \\
(-2.645)\end{array}$ & $\begin{array}{c}-0.164 \\
(-0.852)\end{array}$ & $\begin{array}{c}0.170 \\
(1.513)\end{array}$ & $\begin{array}{c}0.357 \\
(1.629)\end{array}$ \\
\hline Employment Density & $\begin{array}{l}0.003^{*} \\
(0.040)\end{array}$ & $\begin{array}{c}0.152 \\
(2.233)\end{array}$ & $\begin{array}{c}0.158 \\
(1.662)\end{array}$ & $\begin{array}{c}-0.473 \\
(-1.529)\end{array}$ & $\begin{array}{l}0.111^{\star *} \\
(4.494)\end{array}$ & $\begin{array}{c}0.060 \\
(0.608)\end{array}$ & $\begin{array}{l}0.220^{\star *} \\
(2.787)\end{array}$ & $\begin{array}{c}0.058 \\
(0.553)\end{array}$ & $\begin{array}{c}-0.097 \\
(-0.858)\end{array}$ \\
\hline
\end{tabular}

Mixed Land Use

low (reference) 


\begin{tabular}{|c|c|c|c|c|c|c|c|c|c|}
\hline & \multirow{3}{*}{$\begin{array}{c}\mathrm{DV}=3 \text {-level } \\
\text { Physical Activity } \\
\text { Ordered } \\
\text { Logistic Model } \\
\text { Coef. } \\
\text { (z-value) }\end{array}$} & \multicolumn{2}{|c|}{$\begin{array}{c}\text { DV=Weekly Exercise } \\
\text { Walk Trip Rate }\end{array}$} & \multicolumn{2}{|c|}{$\begin{array}{c}\text { DV= Weekly Non-exercise } \\
\text { Walk Trip Rate }\end{array}$} & \multicolumn{2}{|c|}{$\begin{array}{c}\text { DV=Weekly Exercise } \\
\text { Bike Trip Rate }\end{array}$} & \multicolumn{2}{|c|}{$\begin{array}{c}\mathrm{DV}=\text { Weekly Non-exercise } \\
\text { Bike Trip Rate }\end{array}$} \\
\hline & & $\begin{array}{l}\text { Zero } \\
\text { Model }\end{array}$ & $\begin{array}{l}\text { Count } \\
\text { Model }\end{array}$ & $\begin{array}{l}\text { Zero } \\
\text { Model }\end{array}$ & $\begin{array}{l}\text { Count } \\
\text { Model }\end{array}$ & $\begin{array}{l}\text { Zero } \\
\text { Model }\end{array}$ & $\begin{array}{l}\text { Count } \\
\text { Model }\end{array}$ & $\begin{array}{l}\text { Zero } \\
\text { Model }\end{array}$ & $\begin{array}{l}\text { Count } \\
\text { Model }\end{array}$ \\
\hline & & $\begin{array}{c}\text { Coef. } \\
\text { (z-value) }\end{array}$ & $\begin{array}{c}\text { Coef. } \\
\text { (z-value) }\end{array}$ & $\begin{array}{c}\text { Coef. } \\
\text { (z-value) }\end{array}$ & $\begin{array}{c}\text { Coef. } \\
\text { (z-value) }\end{array}$ & $\begin{array}{c}\text { Coef. } \\
\text { (z-value) }\end{array}$ & $\begin{array}{c}\text { Coef. } \\
\text { (z-value) }\end{array}$ & $\begin{array}{c}\text { Coef. } \\
\text { (z-value) }\end{array}$ & $\begin{array}{c}\text { Coef. } \\
\text { (z-value) }\end{array}$ \\
\hline medium & $\begin{array}{c}0.039 \\
(1.136)\end{array}$ & $\begin{array}{l}-0.022 \\
(-1.057)\end{array}$ & $\begin{array}{c}0.004 \\
(0.125)\end{array}$ & $\begin{array}{l}-0.095^{\star *} \\
(-2.603)\end{array}$ & $\begin{array}{c}0.081 \\
(1.873)\end{array}$ & $\begin{array}{l}-0.065 \\
(-0.940)\end{array}$ & $\begin{array}{l}-0.157 \\
(-3.009)\end{array}$ & $\begin{array}{l}-0.074 \\
(-0.523)\end{array}$ & $\begin{array}{l}-0.032 \\
(-0.509)\end{array}$ \\
\hline high & $\begin{array}{c}0.038 \\
(0.667)\end{array}$ & $\begin{array}{l}-0.064 \\
(-1.328)\end{array}$ & $\begin{array}{l}-0.027 \\
(-0.867)\end{array}$ & $\begin{array}{l}-0.095^{\star} \\
(-2.478)\end{array}$ & $\begin{array}{l}-0.015 \\
(-0.345)\end{array}$ & $\begin{array}{c}0.006 \\
(0.054)\end{array}$ & $\begin{array}{l}-0.131 \\
(-1.669)\end{array}$ & $\begin{array}{c}0.002 \\
(0.024)\end{array}$ & $\begin{array}{c}0.066 \\
(0.662)\end{array}$ \\
\hline $\begin{array}{l}\text { Median Household } \\
\text { Income }\end{array}$ & $\begin{array}{l}0.022^{* *} \\
(.3568)\end{array}$ & $\begin{array}{l}-0.019^{* *} \\
(-2.943)\end{array}$ & $\begin{array}{c}0.002 \\
(0.523)\end{array}$ & $\begin{array}{l}-0.001 \\
(-0.174)\end{array}$ & $\begin{array}{c}0.001 \\
(0.133)\end{array}$ & $\begin{array}{l}-0.032^{*} \\
(-2.471)\end{array}$ & $\begin{array}{c}0.001 \\
(0.142)\end{array}$ & $\begin{array}{c}-0.017 \\
(-1.478)\end{array}$ & $\begin{array}{l}-0.023^{* *} \\
(-3.635)\end{array}$ \\
\hline Poverty Rate & $\begin{array}{c}-0.045 \\
(-0.226)\end{array}$ & $\begin{array}{c}-0.181 \\
(-1.543)\end{array}$ & $\begin{array}{c}-0.067 \\
(-0.590)\end{array}$ & $\begin{array}{c}-0.412 \\
(-2.387)\end{array}$ & $\begin{array}{c}0.171 \\
(0.950)\end{array}$ & $\begin{array}{c}-0.282 \\
(-0.809)\end{array}$ & $\begin{array}{c}0.067 \\
(0.322)\end{array}$ & $\begin{array}{l}-0.803^{*} \\
(-2.203)\end{array}$ & $\begin{array}{c}-0.307 \\
(-1.084)\end{array}$ \\
\hline Share of White & $\begin{array}{c}0.335 \\
(1.755)\end{array}$ & $\begin{array}{l}-0.133 \\
(0.911)\end{array}$ & $\begin{array}{c}0.071 \\
(1.095)\end{array}$ & $\begin{array}{c}-0.251 \\
(-1.563)\end{array}$ & $\begin{array}{l}-0.215^{*} \\
(-2.021)\end{array}$ & $\begin{array}{c}0.152 \\
(0.730)\end{array}$ & $\begin{array}{l}-0.120 \\
(0.665)\end{array}$ & $\begin{array}{l}-0.493^{*} \\
(-2.137)\end{array}$ & $\begin{array}{c}-0.124 \\
(-0.603)\end{array}$ \\
\hline Share of Black & $\begin{array}{c}0.245 \\
(0.992)\end{array}$ & $\begin{array}{c}-0.007 \\
(-0.037)\end{array}$ & $\begin{array}{c}0.094 \\
(1.160)\end{array}$ & $\begin{array}{c}-0.187 \\
(-0.888)\end{array}$ & $\begin{array}{c}-0.278 \\
(-1.155)\end{array}$ & $\begin{array}{c}0.142 \\
(0.970)\end{array}$ & $\begin{array}{c}0.162 \\
(0.638)\end{array}$ & $\begin{array}{l}-0.692^{* *} \\
(-2.923)\end{array}$ & $\begin{array}{c}-0.331 \\
(-0.898)\end{array}$ \\
\hline Share of Hispanic & $\begin{array}{c}-0.100 \\
(-0.608)\end{array}$ & $\begin{array}{c}-0.089 \\
(-0.625)\end{array}$ & $\begin{array}{c}0.065 \\
(0.857)\end{array}$ & $\begin{array}{c}0.330 \\
(1.799)\end{array}$ & $\begin{array}{l}-0.407^{* *} \\
(-3.866)\end{array}$ & $\begin{array}{c}0.155 \\
(0.751)\end{array}$ & $\begin{array}{c}0.066 \\
(0.400)\end{array}$ & $\begin{array}{c}0.003 \\
(0.009)\end{array}$ & $\begin{array}{c}-0.208 \\
(-0.680)\end{array}$ \\
\hline \multicolumn{10}{|l|}{$\begin{array}{l}\text { Individual } \\
\text { Socio-demographics }\end{array}$} \\
\hline $\begin{array}{l}\text { Sex } \\
(\text { female=1) }\end{array}$ & $\begin{array}{l}-0.420^{* *} \\
(-32.541)\end{array}$ & $\begin{array}{l}-0.141^{* *} \\
(-7.648)\end{array}$ & $\begin{array}{l}-0.074^{* *} \\
(-4.252)\end{array}$ & $\begin{array}{l}0.078^{* *} \\
(3.939)\end{array}$ & $\begin{array}{l}-0.058^{* *} \\
(-4.129)\end{array}$ & $\begin{array}{l}0.322^{\star *} \\
(8.863)\end{array}$ & $\begin{array}{l}-0.299 * * \\
(-8.300)\end{array}$ & $\begin{array}{l}0.492^{* *} \\
(9.334)\end{array}$ & $\begin{array}{l}-0.263^{* *} \\
(-3.294)\end{array}$ \\
\hline \multicolumn{10}{|l|}{ Age } \\
\hline $5-12$ & $\begin{array}{l}0.690 * * \\
(3.592)\end{array}$ & $\begin{array}{l}-0.099 \\
(-0.777)\end{array}$ & $\begin{array}{l}-0.032 \\
(-0.267)\end{array}$ & $\begin{array}{c}0.012 \\
(0.078)\end{array}$ & $\begin{array}{c}-0.273 \\
(-1.629)\end{array}$ & $\begin{array}{l}-1.074^{\star *} \\
(-3.605)\end{array}$ & $\begin{array}{l}-0.405 \\
(-1.293)\end{array}$ & $\begin{array}{l}-0.477 \\
(-1.780)\end{array}$ & $\begin{array}{l}-0.351 \\
(-1.839)\end{array}$ \\
\hline $13-17$ & $\begin{array}{c}0.742 \\
(5.556)\end{array}$ & $\begin{array}{l}-0.169 \\
(-1.801)\end{array}$ & $\begin{array}{c}0.023 \\
(0.310)\end{array}$ & $\begin{array}{l}-0.042 \\
(-0.459)\end{array}$ & $\begin{array}{l}-0.192 \\
(-1.337)\end{array}$ & $\begin{array}{l}-0.337 \\
(-1.222)\end{array}$ & $\begin{array}{l}-0.209 \\
(-0.688)\end{array}$ & $\begin{array}{l}-0.047 \\
(-0.249)\end{array}$ & $\begin{array}{l}-0.264 \\
(-1.322)\end{array}$ \\
\hline $18-24$ & $\begin{array}{l}0.155^{\star *} \\
(3.115)\end{array}$ & $\begin{array}{l}0.126^{*} \\
(2.205)\end{array}$ & $\begin{array}{c}0.023 \\
(0.514)\end{array}$ & $\begin{array}{c}0.093 \\
(1.615)\end{array}$ & $\begin{array}{c}0.030 \\
(0.549)\end{array}$ & $\begin{array}{c}0.224 \\
(1.746)\end{array}$ & $\begin{array}{c}0.081 \\
(0.666)\end{array}$ & $\begin{array}{c}0.205 \\
(1.411)\end{array}$ & $\begin{array}{c}0.273 \\
(1.506)\end{array}$ \\
\hline $25-34$ & $\begin{array}{l}0.095^{*} \\
(2.324)\end{array}$ & $\begin{array}{c}0.029 \\
(0.874)\end{array}$ & $\begin{array}{l}-0.042 \\
(-1.688)\end{array}$ & $\begin{array}{l}-0.012 \\
(-0.238)\end{array}$ & $\begin{array}{l}0.064^{*} \\
(2.098)\end{array}$ & $\begin{array}{c}0.160 \\
(1.099)\end{array}$ & $\begin{array}{c}0.133 \\
(0.648)\end{array}$ & $\begin{array}{l}-0.116 \\
(-1.323)\end{array}$ & $\begin{array}{l}-0.060 \\
(-0.490)\end{array}$ \\
\hline $\begin{array}{l}35-44 \\
\text { (reference) }\end{array}$ & -- & -- & -- & -- & -- & -- & -- & -- & -- \\
\hline
\end{tabular}




\begin{tabular}{|c|c|c|c|c|c|c|c|c|c|}
\hline & \multirow{3}{*}{$\begin{array}{c}\text { DV }=3 \text {-level } \\
\text { Physical Activity } \\
\text { Ordered } \\
\text { Logistic Model } \\
\text { Coef. } \\
\text { (z-value) }\end{array}$} & \multicolumn{2}{|c|}{$\begin{array}{c}\text { DV=Weekly Exercise } \\
\text { Walk Trip Rate }\end{array}$} & \multicolumn{2}{|c|}{$\begin{array}{c}\text { DV=Weekly Non-exercise } \\
\text { Walk Trip Rate }\end{array}$} & \multicolumn{2}{|c|}{$\begin{array}{c}\text { DV=Weekly Exercise } \\
\text { Bike Trip Rate }\end{array}$} & \multicolumn{2}{|c|}{$\begin{array}{c}\text { DV }=\text { Weekly Non-exercise } \\
\text { Bike Trip Rate }\end{array}$} \\
\hline & & $\begin{array}{l}\text { Zero } \\
\text { Model }\end{array}$ & $\begin{array}{l}\text { Count } \\
\text { Model }\end{array}$ & $\begin{array}{l}\text { Zero } \\
\text { Model }\end{array}$ & $\begin{array}{l}\text { Count } \\
\text { Model }\end{array}$ & $\begin{array}{l}\text { Zero } \\
\text { Model }\end{array}$ & $\begin{array}{l}\text { Count } \\
\text { Model }\end{array}$ & $\begin{array}{l}\text { Zero } \\
\text { Model }\end{array}$ & $\begin{array}{l}\text { Count } \\
\text { Model }\end{array}$ \\
\hline & & $\begin{array}{c}\text { Coef. } \\
\text { (z-value) }\end{array}$ & $\begin{array}{c}\text { Coef. } \\
\text { (z-value) }\end{array}$ & $\begin{array}{c}\text { Coef. } \\
\text { (z-value) }\end{array}$ & $\begin{array}{c}\text { Coef. } \\
\text { (z-value) }\end{array}$ & $\begin{array}{c}\text { Coef. } \\
\text { (z-value) }\end{array}$ & $\begin{array}{c}\text { Coef. } \\
\text { (z-value) }\end{array}$ & $\begin{array}{c}\text { Coef. } \\
\text { (z-value) }\end{array}$ & $\begin{array}{c}\text { Coef. } \\
\text { (z-value) }\end{array}$ \\
\hline $45-54$ & $\begin{array}{l}-0.041 \\
(-1.005)\end{array}$ & $\begin{array}{l}-0.085 \\
(-1.785)\end{array}$ & $\begin{array}{l}0.099^{* *} \\
(5.415)\end{array}$ & $\begin{array}{l}0.142^{* *} \\
(2.980)\end{array}$ & $\begin{array}{c}0.056 \\
(1.462)\end{array}$ & $\begin{array}{l}-0.022 \\
(-0.545)\end{array}$ & $\begin{array}{c}0.041 \\
(0.500)\end{array}$ & $\begin{array}{l}0.276^{\star *} \\
(4.327)\end{array}$ & $\begin{array}{l}-0.064 \\
(-0.495)\end{array}$ \\
\hline $55-64$ & $\begin{array}{l}-0.027 \\
(-0.664)\end{array}$ & $\begin{array}{l}-0.108^{\star *} \\
(-4.107)\end{array}$ & $\begin{array}{l}0.164^{* *} \\
(6.113)\end{array}$ & $\begin{array}{l}0.189^{\star *} \\
(3.764)\end{array}$ & $\begin{array}{l}0.062^{*} \\
(2.255)\end{array}$ & $\begin{array}{c}0.003 \\
(0.055)\end{array}$ & $\begin{array}{c}0.181 \\
(1.439)\end{array}$ & $\begin{array}{c}0.603 \\
(4.236)\end{array}$ & $\begin{array}{c}0.049 \\
(0.480)\end{array}$ \\
\hline $65+$ & $\begin{array}{c}-0.145^{* *} \\
(-2.811)\end{array}$ & $\begin{array}{l}0.160^{* *} \\
(5.925)\end{array}$ & $\begin{array}{l}0.155^{\star *} \\
(4.636)\end{array}$ & $\begin{array}{l}0.349^{* *} \\
(5.878)\end{array}$ & $\begin{array}{c}0.018 \\
(0.531)\end{array}$ & $\begin{array}{l}0.628^{\star *} \\
(6.329)\end{array}$ & $\begin{array}{c}0.179 \\
(1.217)\end{array}$ & $\begin{array}{c}1.225 \\
(8.372)\end{array}$ & $\begin{array}{c}-0.034 \\
(-0.306)\end{array}$ \\
\hline \multicolumn{10}{|l|}{ Household Income } \\
\hline$<\$ 25 k$ & $\begin{array}{c}-0.052 \\
(-0.865)\end{array}$ & $\begin{array}{l}-0.096^{*} \\
(-2.418)\end{array}$ & $\begin{array}{c}0.087 \\
(1.813)\end{array}$ & $\begin{array}{l}-0.095^{\star} \\
(-2.530)\end{array}$ & $\begin{array}{l}0.087^{*} \\
(2.006)\end{array}$ & $\begin{array}{c}-0.149 \\
(-1.730)\end{array}$ & $\begin{array}{c}0.124 \\
(1.096)\end{array}$ & $\begin{array}{c}-0.110 \\
(-0.866)\end{array}$ & $\begin{array}{c}0.093 \\
(0.856)\end{array}$ \\
\hline$\$ 25 k-\$ 50 k$ & $\begin{array}{c}0.019 \\
(0.388)\end{array}$ & $\begin{array}{c}0.024 \\
(0.532)\end{array}$ & $\begin{array}{c}0.029 \\
(1.053)\end{array}$ & $\begin{array}{c}0.057 \\
(1.204)\end{array}$ & $\begin{array}{c}0.045^{\star} \\
(1.960)\end{array}$ & $\begin{array}{c}-0.041 \\
(-0.424)\end{array}$ & $\begin{array}{c}-0.107 \\
(-0.973)\end{array}$ & $\begin{array}{l}-0.043 \\
(0.403)\end{array}$ & $\begin{array}{c}-0.049 \\
(-0.492)\end{array}$ \\
\hline $\begin{array}{l}\$ 50 \mathrm{k}-\$ 75 \\
\text { (reference) }\end{array}$ & -- & -- & -- & -- & -- & -- & - & -- & -- \\
\hline$\$ 75-\$ 100 k$ & $\begin{array}{c}0.018 \\
(0.739)\end{array}$ & $\begin{array}{c}-0.102 \\
(-1.908)\end{array}$ & $\begin{array}{l}-0.019 \\
(-0.671)\end{array}$ & $\begin{array}{c}0.064 \\
(1.002)\end{array}$ & $\begin{array}{c}-0.021 \\
(-0.554)\end{array}$ & $\begin{array}{c}-0.163 \\
(-1.828)\end{array}$ & $\begin{array}{l}-0.103 \\
(-1.047)\end{array}$ & $\begin{array}{c}0.030 \\
(0.280)\end{array}$ & $\begin{array}{l}-0.060 \\
(-0.581)\end{array}$ \\
\hline$>\$ 100 k$ & $\begin{array}{l}0.221^{* *} \\
(4.308)\end{array}$ & $\begin{array}{l}-0.081 \\
(-1.881)\end{array}$ & $\begin{array}{c}-0.034 \\
(-1.472)\end{array}$ & $\begin{array}{c}0.025 \\
(0.598)\end{array}$ & $\begin{array}{c}0.028 \\
(0.731)\end{array}$ & $\begin{array}{l}-0.100 \\
(-1.440)\end{array}$ & $\begin{array}{l}-0.095 \\
(-1.502)\end{array}$ & $\begin{array}{c}-0.072 \\
(-2.154)\end{array}$ & $\begin{array}{c}-0.122 \\
(-1.597)\end{array}$ \\
\hline \multicolumn{10}{|l|}{ Education } \\
\hline n.a. $($ age $<16)$ & $\begin{array}{c}-0.096 \\
(-0.457)\end{array}$ & $\begin{array}{c}0.096 \\
(1.065)\end{array}$ & $\begin{array}{c}0.048 \\
(0.494)\end{array}$ & $\begin{array}{c}-0.013 \\
(-0.134)\end{array}$ & $\begin{array}{c}-0.035 \\
(-0.553)\end{array}$ & $\begin{array}{c}-0.138 \\
(-0.636)\end{array}$ & $\begin{array}{c}0.323 \\
(0.945)\end{array}$ & $\begin{array}{c}-0.671 \\
(-2.707)\end{array}$ & $\begin{array}{c}0.194 \\
(0.870)\end{array}$ \\
\hline below high school & $\begin{array}{c}-0.052 \\
(-0.729)\end{array}$ & $\begin{array}{c}0.065 \\
(1.753)\end{array}$ & $\begin{array}{c}-0.057 \\
(-1.126)\end{array}$ & $\begin{array}{c}0.035 \\
(0.502)\end{array}$ & $\begin{array}{c}-0.039 \\
(-0.652)\end{array}$ & $\begin{array}{c}-0.091 \\
(-0.720)\end{array}$ & $\begin{array}{c}-0.113 \\
(0.382)\end{array}$ & $\begin{array}{c}-0.306 \\
(-2.885)\end{array}$ & $\begin{array}{c}0.035 \\
(0.211)\end{array}$ \\
\hline $\begin{array}{l}\text { high school } \\
\text { (reference) }\end{array}$ & -- & -- & -- & -- & -- & -- & -- & -- & -- \\
\hline $\begin{array}{l}\text { some college } \\
\text { education }\end{array}$ & $\begin{array}{l}0.171^{* *} \\
(6.424)\end{array}$ & $\begin{array}{l}-0.234^{\star *} \\
(-7.203)\end{array}$ & $\begin{array}{l}-0.041^{*} \\
(-2.014)\end{array}$ & $\begin{array}{l}-0.083^{*} \\
(-1.995)\end{array}$ & $\begin{array}{c}-0.030 \\
(-0.903)\end{array}$ & $\begin{array}{l}-0.277^{* *} \\
(-3.526)\end{array}$ & $\begin{array}{l}-0.194 \\
(-1.121)\end{array}$ & $\begin{array}{c}-0.129 \\
(-1.463)\end{array}$ & $\begin{array}{l}-0.136 \\
(-1.166)\end{array}$ \\
\hline bachelor & $\begin{array}{c}0.334^{* *} \\
(10.547)\end{array}$ & $\begin{array}{l}-0.516^{\star *} \\
(-14.950)\end{array}$ & $\begin{array}{c}0.007 \\
(0.537)\end{array}$ & $\begin{array}{l}-0.235^{\star *} \\
(-5.297)\end{array}$ & $\begin{array}{c}-0.103 \\
(-1.914)\end{array}$ & $\begin{array}{l}-0.635^{* *} \\
(-10.982)\end{array}$ & $\begin{array}{l}-0.305 \\
(-1.794)\end{array}$ & $\begin{array}{l}-0.439^{\star *} \\
(-3.593)\end{array}$ & $\begin{array}{l}-0.065 \\
(-0.560)\end{array}$ \\
\hline graduate degree & $\begin{array}{c}0.469^{\star *} \\
(14.291)\end{array}$ & $\begin{array}{l}-0.643^{* *} \\
(-14.511)\end{array}$ & $\begin{array}{c}-0.005 \\
(-0.223)\end{array}$ & $\begin{array}{c}-0.403 \\
(-8.308)\end{array}$ & $\begin{array}{c}-0.079 \\
(-1.627)\end{array}$ & $\begin{array}{l}-0.759^{\star *} \\
(-7.514)\end{array}$ & $\begin{array}{c}-0.250 \\
(-1.429)\end{array}$ & $\begin{array}{l}-0.789^{* *} \\
(-7.525)\end{array}$ & $\begin{array}{c}0.171 \\
(1.445)\end{array}$ \\
\hline
\end{tabular}




\begin{tabular}{|c|c|c|c|c|c|c|c|c|c|}
\hline & \multirow{3}{*}{$\begin{array}{c}D V=3 \text {-level } \\
\text { Physical Activity } \\
\\
\text { Ordered } \\
\text { Logistic Model } \\
\text { Coef. } \\
\text { (z-value) }\end{array}$} & \multicolumn{2}{|c|}{$\begin{array}{c}\text { DV =Weekly Exercise } \\
\text { Walk Trip Rate }\end{array}$} & \multicolumn{2}{|c|}{$\begin{array}{c}\text { DV=Weekly Non-exercise } \\
\text { Walk Trip Rate }\end{array}$} & \multicolumn{2}{|c|}{$\begin{array}{c}\text { DV=Weekly Exercise } \\
\text { Bike Trip Rate }\end{array}$} & \multicolumn{2}{|c|}{$\begin{array}{c}\text { DV }=\text { Weekly Non-exercise } \\
\text { Bike Trip Rate }\end{array}$} \\
\hline & & $\begin{array}{l}\text { Zero } \\
\text { Model }\end{array}$ & $\begin{array}{l}\text { Count } \\
\text { Model }\end{array}$ & $\begin{array}{l}\text { Zero } \\
\text { Model }\end{array}$ & $\begin{array}{l}\text { Count } \\
\text { Model }\end{array}$ & $\begin{array}{l}\text { Zero } \\
\text { Model }\end{array}$ & $\begin{array}{l}\text { Count } \\
\text { Model }\end{array}$ & $\begin{array}{l}\text { Zero } \\
\text { Model }\end{array}$ & $\begin{array}{l}\text { Count } \\
\text { Model }\end{array}$ \\
\hline & & $\begin{array}{c}\text { Coef. } \\
\text { (z-value) }\end{array}$ & $\begin{array}{c}\text { Coef. } \\
\text { (z-value) }\end{array}$ & $\begin{array}{c}\text { Coef. } \\
\text { (z-value) }\end{array}$ & $\begin{array}{c}\text { Coef. } \\
\text { (z-value) }\end{array}$ & $\begin{array}{c}\text { Coef. } \\
\text { (z-value) }\end{array}$ & $\begin{array}{c}\text { Coef. } \\
\text { (z-value) }\end{array}$ & $\begin{array}{c}\text { Coef. } \\
\text { (z-value) }\end{array}$ & $\begin{array}{c}\text { Coef. } \\
\text { (z-value) }\end{array}$ \\
\hline \multicolumn{10}{|l|}{ Race/ethnicity } \\
\hline White (reference) & -- & -- & -- & -- & -- & -- & -- & -- & -- \\
\hline Black & $\begin{array}{c}0.035 \\
(0.634)\end{array}$ & $\begin{array}{l}-0.165^{\star *} \\
(-4.144)\end{array}$ & $\begin{array}{l}-0.014 \\
(-0.324)\end{array}$ & $\begin{array}{c}0.100 \\
(1.614)\end{array}$ & $\begin{array}{l}-0.069 \\
(-1.656)\end{array}$ & $\begin{array}{c}0.025 \\
(0.255)\end{array}$ & $\begin{array}{l}-0.140^{*} \\
(-2.255)\end{array}$ & $\begin{array}{l}0.501^{\star *} \\
(3.893)\end{array}$ & $\begin{array}{l}-0.182 \\
(-2.399)\end{array}$ \\
\hline Asian & $\begin{array}{l}-0.678^{* *} \\
(-14.104)\end{array}$ & $\begin{array}{l}-0.013 \\
(-0.338)\end{array}$ & $\begin{array}{l}-0.016 \\
(-0.448)\end{array}$ & $\begin{array}{l}0.417^{* *} \\
(6.435)\end{array}$ & $\begin{array}{l}-0.298^{* *} \\
(-7.748)\end{array}$ & $\begin{array}{l}0.281^{* *} \\
(3.083)\end{array}$ & $\begin{array}{c}0.020 \\
(0.114)\end{array}$ & $\begin{array}{l}0.642^{* *} \\
(6.103)\end{array}$ & $\begin{array}{c}-0.057 \\
(-0.500)\end{array}$ \\
\hline Hispanic & $\begin{array}{l}-0.127^{* *} \\
(-2.793)\end{array}$ & $\begin{array}{l}-0.085^{\star} \\
(-2.570)\end{array}$ & $\begin{array}{l}-0.035 \\
(-0.699)\end{array}$ & $\begin{array}{c}0.237 \\
(5.761)\end{array}$ & $\begin{array}{l}-0.161^{\star *} \\
(-4.903)\end{array}$ & $\begin{array}{l}0.124^{*} \\
(1.987)\end{array}$ & $\begin{array}{c}0.052 \\
(0.588)\end{array}$ & $\begin{array}{l}0.371^{\star *} \\
(5.653)\end{array}$ & $\begin{array}{c}-0.151 \\
(-1.756)\end{array}$ \\
\hline Other & $\begin{array}{c}0.131 \\
(1.530)\end{array}$ & $\begin{array}{l}-0.108 \\
(-1.430)\end{array}$ & $\begin{array}{l}-0.008 \\
(-0.302)\end{array}$ & $\begin{array}{c}0.024 \\
(0.531)\end{array}$ & $\begin{array}{l}-0.055 \\
(-0.939)\end{array}$ & $\begin{array}{c}0.170 \\
(1.355)\end{array}$ & $\begin{array}{c}0.190 \\
(1.127)\end{array}$ & $\begin{array}{c}0.158 \\
(1.841)\end{array}$ & $\begin{array}{l}-0.044 \\
(-0.425)\end{array}$ \\
\hline \multicolumn{10}{|l|}{ Employment Status } \\
\hline working (reference) & -- & -- & -- & -- & -- & -- & -- & -- & -- \\
\hline $\begin{array}{l}\text { temporarily not } \\
\text { working }\end{array}$ & $\begin{array}{l}-0.128 \\
(-1.751)\end{array}$ & $\begin{array}{l}-0.070 \\
(-1.382)\end{array}$ & $\begin{array}{c}0.015 \\
(0.459)\end{array}$ & $\begin{array}{c}0.066 \\
(1.682)\end{array}$ & $\begin{array}{l}-0.134^{\star *} \\
(-2.849)\end{array}$ & $\begin{array}{c}0.052 \\
(0.405)\end{array}$ & $\begin{array}{c}0.137 \\
(0.805)\end{array}$ & $\begin{array}{c}0.041 \\
(0313)\end{array}$ & $\begin{array}{l}-0.190 \\
(-1.217)\end{array}$ \\
\hline $\begin{array}{l}\text { look for } \\
\text { work/un } \\
\text { employed }\end{array}$ & $-0.192^{* *}$ & $-0.284^{* *}$ & $0.262^{* *}$ & $\begin{array}{l}-0.079 \\
(-1.939)\end{array}$ & $\begin{array}{c}0.006 \\
(0.088)\end{array}$ & $\begin{array}{l}-0.306 \\
(-1.917)\end{array}$ & $\begin{array}{c}0.018 \\
(0.079)\end{array}$ & $\begin{array}{l}-0.294 \\
(-2.213)\end{array}$ & $\begin{array}{l}-0.015 \\
(-0.116)\end{array}$ \\
\hline homemaker & $\begin{array}{l}-0.107^{* *} \\
(-5.646)\end{array}$ & $\begin{array}{l}-0.177 \\
(-4.448)\end{array}$ & $\begin{array}{l}0.070^{* *} \\
(3.377)\end{array}$ & $\begin{array}{l}-0.116^{\star *} \\
(-3.552)\end{array}$ & $\begin{array}{l}-0.127^{* *} \\
(-4.298)\end{array}$ & $\begin{array}{c}0.183 \\
(1.263)\end{array}$ & $\begin{array}{c}0.191 \\
(1.086)\end{array}$ & $\begin{array}{c}0.035 \\
(0.213)\end{array}$ & $\begin{array}{c}0.067 \\
(0.416)\end{array}$ \\
\hline going to school & $\begin{array}{c}0.004 \\
(0.040)\end{array}$ & $\begin{array}{c}0.012 \\
(0.204)\end{array}$ & $\begin{array}{l}0.098^{* *} \\
(3.417)\end{array}$ & $\begin{array}{l}-0.335^{\star *} \\
(-8.894)\end{array}$ & $\begin{array}{l}0.220^{* *} \\
(3.464)\end{array}$ & $\begin{array}{c}0.017 \\
(0.089)\end{array}$ & $\begin{array}{c}-0.007 \\
(-0.044)\end{array}$ & $\begin{array}{l}-0.591^{*} \\
(-2.447)\end{array}$ & $\begin{array}{c}0.263 \\
(1.320)\end{array}$ \\
\hline retired & $\begin{array}{l}-0.260^{* *} \\
(-11.290)\end{array}$ & $\begin{array}{c}-0.235^{\star *} \\
(-5.166)\end{array}$ & $\begin{array}{l}0.092^{* *} \\
(3.972)\end{array}$ & $\begin{array}{c}0.091 \\
(1.831)\end{array}$ & $\begin{array}{l}-0.084^{* *} \\
(-2.756)\end{array}$ & $\begin{array}{c}0.025 \\
(0.378)\end{array}$ & $\begin{array}{c}0.179 \\
(1.813)\end{array}$ & $\begin{array}{c}-0.030 \\
(-0.175)\end{array}$ & $\begin{array}{c}-0.066 \\
(-0.509)\end{array}$ \\
\hline something else & $\begin{array}{l}-0.515^{\star *} \\
(-12.299)\end{array}$ & $\begin{array}{c}-0.044 \\
(-0.945)\end{array}$ & $\begin{array}{l}0.167^{* *} \\
(4.045)\end{array}$ & $\begin{array}{c}0.004 \\
(0.047)\end{array}$ & $\begin{array}{c}-0.071 \\
(-1.949)\end{array}$ & $\begin{array}{c}0.115 \\
(0.575)\end{array}$ & $\begin{array}{c}0.067 \\
(0.358)\end{array}$ & $\begin{array}{c}0.120 \\
(1.434)\end{array}$ & $\begin{array}{c}0.142 \\
(1.082)\end{array}$ \\
\hline n.a. $($ age $<16)$ & $\begin{array}{c}0.179 \\
(1.120)\end{array}$ & $\begin{array}{c}-0.196 \\
(-1.678)\end{array}$ & $\begin{array}{c}0.150 \\
(1.744)\end{array}$ & $\begin{array}{l}-0.578^{\star *} \\
(-5.314)\end{array}$ & $\begin{array}{c}0.216 \\
(1.296)\end{array}$ & $\begin{array}{c}-0.546 \\
(-1.659)\end{array}$ & $\begin{array}{c}0.364 \\
(1.800)\end{array}$ & $\begin{array}{l}-1.243^{\star *} \\
(-4.084)\end{array}$ & $\begin{array}{c}0.257 \\
(0.850)\end{array}$ \\
\hline \multicolumn{10}{|l|}{ Homeownership } \\
\hline own & -- & -- & -- & -- & -- & -- & -- & -- & -- \\
\hline
\end{tabular}




\begin{tabular}{|c|c|c|c|c|c|c|c|c|c|}
\hline & \multirow{3}{*}{$\begin{array}{c}\text { DV }=3 \text {-level } \\
\text { Physical Activity } \\
\text { Ordered } \\
\text { Logistic Model } \\
\text { Coef. } \\
\text { (z-value) }\end{array}$} & \multicolumn{2}{|c|}{$\begin{array}{c}\text { DV=Weekly Exercise } \\
\text { Walk Trip Rate }\end{array}$} & \multicolumn{2}{|c|}{$\begin{array}{c}\text { DV= Weekly Non-exercise } \\
\text { Walk Trip Rate }\end{array}$} & \multicolumn{2}{|c|}{$\begin{array}{c}\text { DV=Weekly Exercise } \\
\text { Bike Trip Rate }\end{array}$} & \multicolumn{2}{|c|}{$\begin{array}{c}\text { DV }=\text { Weekly Non-exercise } \\
\text { Bike Trip Rate }\end{array}$} \\
\hline & & $\begin{array}{l}\text { Zero } \\
\text { Model }\end{array}$ & $\begin{array}{l}\text { Count } \\
\text { Model }\end{array}$ & $\begin{array}{l}\text { Zero } \\
\text { Model }\end{array}$ & $\begin{array}{l}\text { Count } \\
\text { Model }\end{array}$ & $\begin{array}{l}\text { Zero } \\
\text { Model }\end{array}$ & $\begin{array}{l}\text { Count } \\
\text { Model }\end{array}$ & $\begin{array}{l}\text { Zero } \\
\text { Model }\end{array}$ & $\begin{array}{l}\text { Count } \\
\text { Model }\end{array}$ \\
\hline & & $\begin{array}{c}\text { Coef. } \\
\text { (z-value) }\end{array}$ & $\begin{array}{c}\text { Coef. } \\
\text { (z-value) }\end{array}$ & $\begin{array}{c}\text { Coef. } \\
\text { (z-value) }\end{array}$ & $\begin{array}{c}\text { Coef. } \\
\text { (z-value) }\end{array}$ & $\begin{array}{c}\text { Coef. } \\
\text { (z-value) }\end{array}$ & $\begin{array}{c}\text { Coef. } \\
\text { (z-value) }\end{array}$ & $\begin{array}{c}\text { Coef. } \\
\text { (z-value) }\end{array}$ & $\begin{array}{c}\text { Coef. } \\
\text { (z-value) }\end{array}$ \\
\hline rent & $\begin{array}{l}-0.069^{*} \\
(-2.484)\end{array}$ & $\begin{array}{l}-0.019 \\
(-0.550)\end{array}$ & $\begin{array}{l}0.035^{\star} \\
(2.107)\end{array}$ & $\begin{array}{l}-0.310 \\
(-6.682)\end{array}$ & $\begin{array}{l}0.077^{* *} \\
(2.904)\end{array}$ & $\begin{array}{l}0.141^{*} \\
(2.442)\end{array}$ & $\begin{array}{l}0.222^{* *} \\
(3.492)\end{array}$ & $\begin{array}{l}-0.177 \\
(-1.749)\end{array}$ & $\begin{array}{l}0.161^{* *} \\
(2.835)\end{array}$ \\
\hline other arrangement & $\begin{array}{l}-0.055 \\
(-0.424)\end{array}$ & $\begin{array}{c}0.162 \\
(1.492)\end{array}$ & $\begin{array}{c}0.141 \\
(1.644)\end{array}$ & $\begin{array}{l}-0.061 \\
(-0.325)\end{array}$ & $\begin{array}{c}0.074 \\
(0.534)\end{array}$ & $\begin{array}{l}-0.046 \\
(-0.182)\end{array}$ & $\begin{array}{c}0.164 \\
(0.930)\end{array}$ & $\begin{array}{c}-0.192 \\
(-0.722)\end{array}$ & $\begin{array}{c}-0.179 \\
(-0.387)\end{array}$ \\
\hline vehicle ownership & $\begin{array}{l}0.058^{* *} \\
(3.476)\end{array}$ & $\begin{array}{c}0.012 \\
(0.344)\end{array}$ & $\begin{array}{c}0.012 \\
(0.628)\end{array}$ & $\begin{array}{l}0.123^{\star *} \\
(5.406)\end{array}$ & $\begin{array}{l}-0.035 \\
(-0.933)\end{array}$ & $\begin{array}{c}0.000 \\
(0.002)\end{array}$ & $\begin{array}{l}-0.023 \\
(-0.625)\end{array}$ & $\begin{array}{c}0.376 \\
(13.090)\end{array}$ & $\begin{array}{c}-0.038 \\
(-0.774)\end{array}$ \\
\hline \multicolumn{10}{|l|}{$\begin{array}{l}\text { Other control } \\
\text { variables }\end{array}$} \\
\hline $\begin{array}{l}\text { Proxy Report } \\
(\text { yes=1) }\end{array}$ & $\begin{array}{l}-0.089^{* *} \\
(-4.260)\end{array}$ & $\begin{array}{l}0.210^{\star *} \\
(7.584)\end{array}$ & $\begin{array}{c}-0.012 \\
(-0.437)\end{array}$ & $\begin{array}{c}0.280^{* *} \\
(19.979)\end{array}$ & $\begin{array}{l}-0.087 \\
(-3.556)\end{array}$ & $\begin{array}{l}0.138^{* *} \\
(3.792)\end{array}$ & $\begin{array}{c}0.041 \\
(0.470)\end{array}$ & $\begin{array}{c}0.093 \\
(1.187)\end{array}$ & $\begin{array}{c}-0.029 \\
(-0.282)\end{array}$ \\
\hline \multicolumn{10}{|l|}{ Season } \\
\hline spring (reference) & -- & -- & -- & -- & -- & -- & -- & -- & -- \\
\hline summer & $\begin{array}{c}0.020 \\
(0.740)\end{array}$ & $\begin{array}{c}0.016 \\
(0.346)\end{array}$ & $\begin{array}{c}0.049^{*} \\
(2.572)\end{array}$ & $\begin{array}{c}-0.028 \\
(-0.574)\end{array}$ & $\begin{array}{c}0.048 \\
(1.424)\end{array}$ & $\begin{array}{l}-0.203^{* *} \\
(-3.159)\end{array}$ & $\begin{array}{l}0.305^{\star *} \\
(3.439)\end{array}$ & $\begin{array}{c}-0.222 \\
(-1.658)\end{array}$ & $\begin{array}{c}0.121 \\
(1.326)\end{array}$ \\
\hline fall & $\begin{array}{c}-0.033 \\
(-1.549)\end{array}$ & $\begin{array}{l}0.130^{* *} \\
(4.673)\end{array}$ & $\begin{array}{c}-0.000 \\
(-0.018)\end{array}$ & $\begin{array}{l}-0.089^{* *} \\
(-2.644)\end{array}$ & $\begin{array}{c}0.021 \\
(0.405)\end{array}$ & $\begin{array}{c}0.036 \\
(0.752)\end{array}$ & $\begin{array}{l}0.136^{*} \\
(2.437)\end{array}$ & $\begin{array}{c}0.020 \\
(0.188)\end{array}$ & $\begin{array}{c}0.077 \\
(0.747)\end{array}$ \\
\hline winter & $\begin{array}{l}-0.105^{\star *} \\
(-3.387)\end{array}$ & $\begin{array}{c}0.341^{\star *} \\
(10.221)\end{array}$ & $\begin{array}{c}-0.021 \\
(-0.749)\end{array}$ & $\begin{array}{c}0.042 \\
(0.854)\end{array}$ & $\begin{array}{c}0.020 \\
(0.361)\end{array}$ & $\begin{array}{c}0.503 \\
(7.320)\end{array}$ & $\begin{array}{c}0.067 \\
(1.233)\end{array}$ & $\begin{array}{l}0.451^{* *} \\
(5.612)\end{array}$ & $\begin{array}{c}0.050 \\
(0.543)\end{array}$ \\
\hline \multicolumn{10}{|l|}{ Urban Size } \\
\hline $50 k-200 k$ & $\begin{array}{c}-0.050 \\
(-0.642)\end{array}$ & $\begin{array}{c}0.064 \\
(0.772)\end{array}$ & $\begin{array}{c}-0.040 \\
(-1.576)\end{array}$ & $\begin{array}{c}-0.016 \\
(-0.174)\end{array}$ & $\begin{array}{c}-0.012 \\
(-0.240)\end{array}$ & $\begin{array}{c}0.036 \\
(0.402)\end{array}$ & $\begin{array}{c}-0.057 \\
(-0.322)\end{array}$ & $\begin{array}{c}0.006 \\
(0.034)\end{array}$ & $\begin{array}{c}0.080 \\
(0.635)\end{array}$ \\
\hline $200 k-500 k$ & $\begin{array}{c}-0.061 \\
(-1.387)\end{array}$ & $\begin{array}{c}0.000 \\
(0.007)\end{array}$ & $\begin{array}{c}0.030 \\
(0.777)\end{array}$ & $\begin{array}{c}0.034 \\
(0.588)\end{array}$ & $\begin{array}{l}-0.099 \\
(-1.625)\end{array}$ & $\begin{array}{l}-0.056 \\
(-0.394)\end{array}$ & $\begin{array}{l}-0.032 \\
(-0.192)\end{array}$ & $\begin{array}{l}-0.130 \\
(-0.666)\end{array}$ & $\begin{array}{l}-0.054 \\
(-0.581)\end{array}$ \\
\hline $500 \mathrm{k}-1$ million & -- & -- & -- & -- & -- & -- & -- & -- & -- \\
\hline $\begin{array}{l}1+\text { million without } \\
\text { heavy rail }\end{array}$ & $\begin{array}{l}-0.107^{*} \\
(-2.299)\end{array}$ & $\begin{array}{l}-0.053 \\
(-0.983)\end{array}$ & $\begin{array}{l}-0.001 \\
(0.050)\end{array}$ & $\begin{array}{c}0.021 \\
(0.426)\end{array}$ & $\begin{array}{l}-0.083 \\
(-1.846)\end{array}$ & $\begin{array}{c}0.051 \\
(0.461)\end{array}$ & $\begin{array}{l}-0.111 \\
(-0.730)\end{array}$ & $\begin{array}{c}0.019 \\
(0.168)\end{array}$ & $\begin{array}{c}0.099 \\
(1.594)\end{array}$ \\
\hline $\begin{array}{l}1+\text { million with } \\
\text { heavy rail }\end{array}$ & $\begin{array}{c}-0.071 \\
(-1.644)\end{array}$ & $\begin{array}{c}0.058 \\
(0.896)\end{array}$ & $\begin{array}{l}-0.023 \\
(-0.820)\end{array}$ & $\begin{array}{l}-0.114^{*} \\
(-2.246)\end{array}$ & $\begin{array}{c}0.015 \\
(0.378)\end{array}$ & $\begin{array}{l}0.217^{*} \\
(2.084)\end{array}$ & $\begin{array}{l}-0.232 \\
(-1.221)\end{array}$ & $\begin{array}{l}-0.275^{\star} \\
(-2.048)\end{array}$ & $\begin{array}{c}0.037 \\
(0.372)\end{array}$ \\
\hline
\end{tabular}




\begin{tabular}{|c|c|c|c|c|c|c|c|c|c|}
\hline & \multirow{3}{*}{$\begin{array}{c}\text { DV }=3 \text {-level } \\
\text { Physical Activity } \\
\text { Ordered } \\
\text { Logistic Model } \\
\text { Coef. } \\
\text { (z-value) }\end{array}$} & \multicolumn{2}{|c|}{$\begin{array}{c}\text { DV=Weekly Exercise } \\
\text { Walk Trip Rate }\end{array}$} & \multicolumn{2}{|c|}{$\begin{aligned} \text { DV }= & \text { Weekly Non-exercise } \\
& \text { Walk Trip Rate }\end{aligned}$} & \multicolumn{2}{|c|}{$\begin{array}{c}\text { DV=Weekly Exercise } \\
\text { Bike Trip Rate }\end{array}$} & \multicolumn{2}{|c|}{$\begin{array}{c}\text { DV }=\text { Weekly Non-exercise } \\
\text { Bike Trip Rate }\end{array}$} \\
\hline & & $\begin{array}{l}\text { Zero } \\
\text { Model }\end{array}$ & $\begin{array}{l}\text { Count } \\
\text { Model }\end{array}$ & $\begin{array}{l}\text { Zero } \\
\text { Model }\end{array}$ & $\begin{array}{l}\text { Count } \\
\text { Model }\end{array}$ & $\begin{array}{l}\text { Zero } \\
\text { Model }\end{array}$ & $\begin{array}{l}\text { Count } \\
\text { Model }\end{array}$ & $\begin{array}{l}\text { Zero } \\
\text { Model }\end{array}$ & $\begin{array}{l}\text { Count } \\
\text { Model }\end{array}$ \\
\hline & & $\begin{array}{c}\text { Coef. } \\
\text { (z-value) }\end{array}$ & $\begin{array}{c}\text { Coef. } \\
\text { (z-value) }\end{array}$ & $\begin{array}{l}\text { Coef. } \\
\text { (z-value) }\end{array}$ & $\begin{array}{l}\text { Coef. } \\
\text { (z-value) }\end{array}$ & $\begin{array}{c}\text { Coef. } \\
\text { (z-value) }\end{array}$ & $\begin{array}{l}\text { Coef. } \\
\text { (z-value) }\end{array}$ & $\begin{array}{c}\text { Coef. } \\
\text { (z-value) }\end{array}$ & $\begin{array}{c}\text { Coef. } \\
\text { (z-value) }\end{array}$ \\
\hline $\begin{array}{l}\text { not in an urbanized } \\
\text { area }\end{array}$ & $\begin{array}{l}-0.057 \\
(-1.396)\end{array}$ & $\begin{array}{c}0.005 \\
(0.097)\end{array}$ & $\begin{array}{c}0.030 \\
(1.192)\end{array}$ & $\begin{array}{l}-0.086 \\
(-1.728)\end{array}$ & $\begin{array}{l}-0.001 \\
(-0.016)\end{array}$ & $\begin{array}{l}0.018^{*} \\
(0.267)\end{array}$ & $\begin{array}{l}-0.070 \\
(-0.444)\end{array}$ & $\begin{array}{c}0.029 \\
(0.179)\end{array}$ & $\begin{array}{c}0.005 \\
(0.038)\end{array}$ \\
\hline \multicolumn{10}{|l|}{ Census Division } \\
\hline $\begin{array}{l}\text { New England } \\
\text { (reference) }\end{array}$ & -- & -- & -- & -- & -- & -- & -- & -- & -- \\
\hline East North Central & $\begin{array}{l}-0.146^{*} \\
(-2.240)\end{array}$ & $\begin{array}{c}0.071 \\
(0.881)\end{array}$ & $\begin{array}{l}-0.002 \\
(-0.045)\end{array}$ & $\begin{array}{c}0.193 \\
(1.617)\end{array}$ & $\begin{array}{l}-0.036 \\
(-0.737)\end{array}$ & $\begin{array}{l}-0.181 \\
(-1.298)\end{array}$ & $\begin{array}{l}-0.220 \\
(-0.639)\end{array}$ & $\begin{array}{l}-0.185 \\
(-1.456)\end{array}$ & $\begin{array}{c}0.027 \\
(0.207)\end{array}$ \\
\hline East South Central & $\begin{array}{l}-0.278^{* *} \\
(-3.292)\end{array}$ & $\begin{array}{c}0.009 \\
(0.101)\end{array}$ & $\begin{array}{c}0.057 \\
(0.716)\end{array}$ & $\begin{array}{c}0.009 \\
(0.078)\end{array}$ & $\begin{array}{c}0.043 \\
(0.435)\end{array}$ & $\begin{array}{c}0.083 \\
(0.324)\end{array}$ & $\begin{array}{c}-0.546 \\
(-1.453)\end{array}$ & $\begin{array}{c}-0.115 \\
(-0.889)\end{array}$ & $\begin{array}{c}-0.129 \\
(-0.760)\end{array}$ \\
\hline Mid-Atlantic & $\begin{array}{l}-0.174^{*} \\
(-2.202)\end{array}$ & $\begin{array}{c}0.080 \\
(1.069)\end{array}$ & $\begin{array}{c}-0.006 \\
(-0.095)\end{array}$ & $\begin{array}{c}0.005 \\
(0.048)\end{array}$ & $\begin{array}{l}0.092^{*} \\
(2.033)\end{array}$ & $\begin{array}{c}0.048 \\
(0.259)\end{array}$ & $\begin{array}{c}-0.136 \\
(-0.431)\end{array}$ & $\begin{array}{c}0.062 \\
(0.528)\end{array}$ & $\begin{array}{c}0.180 \\
(1.185)\end{array}$ \\
\hline \multirow{2}{*}{ Mountain } & 0.044 & -0.038 & -0.024 & -0.029 & -0.018 & $-0.393^{*}$ & -0.110 & $-0.674^{\star *}$ & 0.080 \\
\hline & $(0.474)$ & $(-0.456)$ & $(-0.494)$ & $(-0.275)$ & $(-0.229)$ & $(-2.292)$ & $(-0.280)$ & $(-3.691)$ & $(0.345)$ \\
\hline Pacific & $\begin{array}{c}0.005 \\
(0.046)\end{array}$ & $\begin{array}{c}-0.080 \\
(-1.002)\end{array}$ & $\begin{array}{c}0.001 \\
(0.011)\end{array}$ & $\begin{array}{c}-0.041 \\
(-0.505)\end{array}$ & $\begin{array}{c}-0.045 \\
(-0.941)\end{array}$ & $\begin{array}{c}-0.223 \\
(-1.235)\end{array}$ & $\begin{array}{c}-0.418 \\
(-1.367)\end{array}$ & $\begin{array}{l}-0.463^{* *} \\
(-4.338)\end{array}$ & $\begin{array}{c}0.130 \\
(0.980)\end{array}$ \\
\hline South Atlantic & $\begin{array}{l}-0.180^{*} \\
(-2.257)\end{array}$ & $\begin{array}{c}0.045 \\
(0.509)\end{array}$ & $\begin{array}{c}0.071 \\
(1.430)\end{array}$ & $\begin{array}{c}-0.002 \\
(-0.023)\end{array}$ & $\begin{array}{l}0.129^{* *} \\
(4.211)\end{array}$ & $\begin{array}{l}-0.262^{*} \\
(-2.250)\end{array}$ & $\begin{array}{c}-0.325 \\
(-1.034)\end{array}$ & $\begin{array}{c}-0.003 \\
(-0.021)\end{array}$ & $\begin{array}{c}0.075 \\
(0.880)\end{array}$ \\
\hline West North Central & $\begin{array}{l}-0.170 \\
(-1.702)\end{array}$ & $\begin{array}{c}0.089 \\
(0.832)\end{array}$ & $\begin{array}{c}0.049 \\
(0.691)\end{array}$ & $\begin{array}{l}0.235^{\star *} \\
(2.696)\end{array}$ & $\begin{array}{l}-0.011 \\
(-0.182)\end{array}$ & $\begin{array}{l}-0.172 \\
(0.685)\end{array}$ & $\begin{array}{l}-0.355 \\
(-0.917)\end{array}$ & $\begin{array}{l}-0.291^{* *} \\
(-2.932)\end{array}$ & $\begin{array}{l}-0.259 \\
(-1.277)\end{array}$ \\
\hline West South Central & $\begin{array}{c}-0.117 \\
(-1.623)\end{array}$ & $\begin{array}{c}0.170 * \\
(2.010)\end{array}$ & $\begin{array}{c}0.002 \\
(0.036)\end{array}$ & $\begin{array}{c}0.057 \\
(0.506)\end{array}$ & $\begin{array}{l}0.156^{*} \\
(2.110)\end{array}$ & $\begin{array}{c}-0.025 \\
(-0.134)\end{array}$ & $\begin{array}{c}-0.291 \\
(-0.736)\end{array}$ & $\begin{array}{c}-0.226 \\
(-1.790)\end{array}$ & $\begin{array}{c}0.049 \\
(0.301)\end{array}$ \\
\hline Intercept & -- & $\begin{array}{l}0.673^{* *} \\
(2.988)\end{array}$ & $\begin{array}{l}1.246^{* *} \\
(11.158)\end{array}$ & $\begin{array}{l}0.467^{*} \\
(2.009)\end{array}$ & $\begin{array}{l}2.194^{\star *} \\
(17.893)\end{array}$ & $\begin{array}{c}2.917 \\
(15.281)\end{array}$ & $\begin{array}{l}1.254^{\star *} \\
(2.289)\end{array}$ & $\begin{array}{l}3.816^{* *} \\
(12.768)\end{array}$ & $\begin{array}{l}1.556^{* *} \\
(8.481)\end{array}$ \\
\hline $\mathrm{N}$ & 261,582 & \multicolumn{2}{|c|}{249,820} & \multicolumn{2}{|c|}{250,267} & \multicolumn{2}{|c|}{250,775} & \multicolumn{2}{|c|}{250,755} \\
\hline
\end{tabular}

Note: *significant at the $5 \%$ or lower level; ${ }^{* *}$ significant at the $1 \%$ or lower level. 


\section{BARRIERS TO WALKING AND BIKING MORE}

For respondents who took a walk or bike trip in the past seven days, they were asked what keeps them from walking/biking more. Respondents were given six options and they could select all that apply. The six options include: 1) no nearby paths or trails, 2) no nearby parks, 3 ) no sidewalks or sidewalks are in poor condition, 4) street crossings are unsafe, 5) heavy traffic with too many cars, and 6) not enough lighting at night.

Among the respondents that were eligible to answer the question "which of the following keeps you from walking more," $38 \%$ of them reported at least one of the six factors that kept them from walking more. Among the respondents that were eligible to answer the question "which of the following keeps you from biking more," $45 \%$ of them reported at least one of the six factors that kept them from biking more. The researchers are more interested in whether people living in the eight geographic locations reported different barriers to walking and biking more.

Figure 2a demonstrates the infrastructural barriers to walking and biking more in the eight geographic locations. The stacked bars represent the composition of respondents in each geographic location based on their responses to the survey question. It seems that no nearby paths or trails was a major barrier to biking more for residents in inner cities of large metropolitan areas and non-metropolitan areas but less of a problem for residents in suburbs of large metropolitan areas and small metropolitan areas. For suburbanites, no nearby parks seems to be a more prominent barrier to biking more.

No sidewalks or sidewalks in poor conditions was the most reported barrier to walking more in all eight geographic locations. Suburbanites in large metropolitan areas and urban residents in small metropolitan areas are more likely to report this problem as a barrier than residents in other geographic locations. No nearby paths and trails was the second most reported barrier to walking more, and residents in more central locations of large metropolitan areas were more likely to report this problem.

Figure $2 \mathrm{~b}$ shows the safety barriers to walking and biking more in the eight geographic locations. Unsafe street crossing did not seem to be a major barrier to walking and biking more in any of the eight geographic locations. Heavy traffic was the most prominent barrier to biking more in large metropolitan areas, particularly in their central locations. Insufficient lighting at night was a major barrier to biking more only in rural areas. Insufficient lighting, however, was consistently reported as the most prominent barrier to walking more in all eight geographic locations. Heavy traffic seemed to be a moderate problem for walking and was more likely to be a problem for residents in central locations in large metropolitan areas. 
a) infrastructure barriers to walking/biking

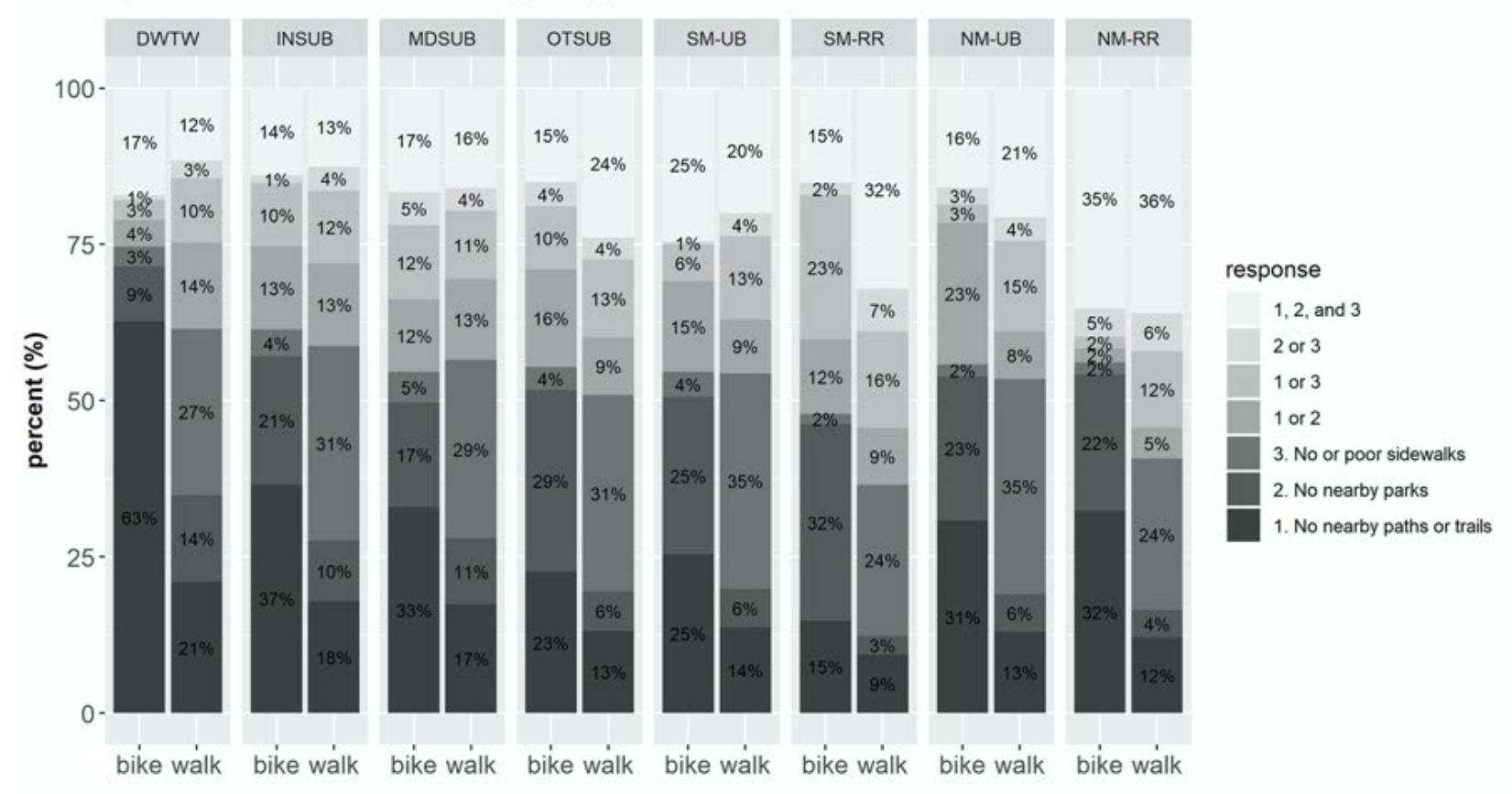

b) safety barriers to walking/biking

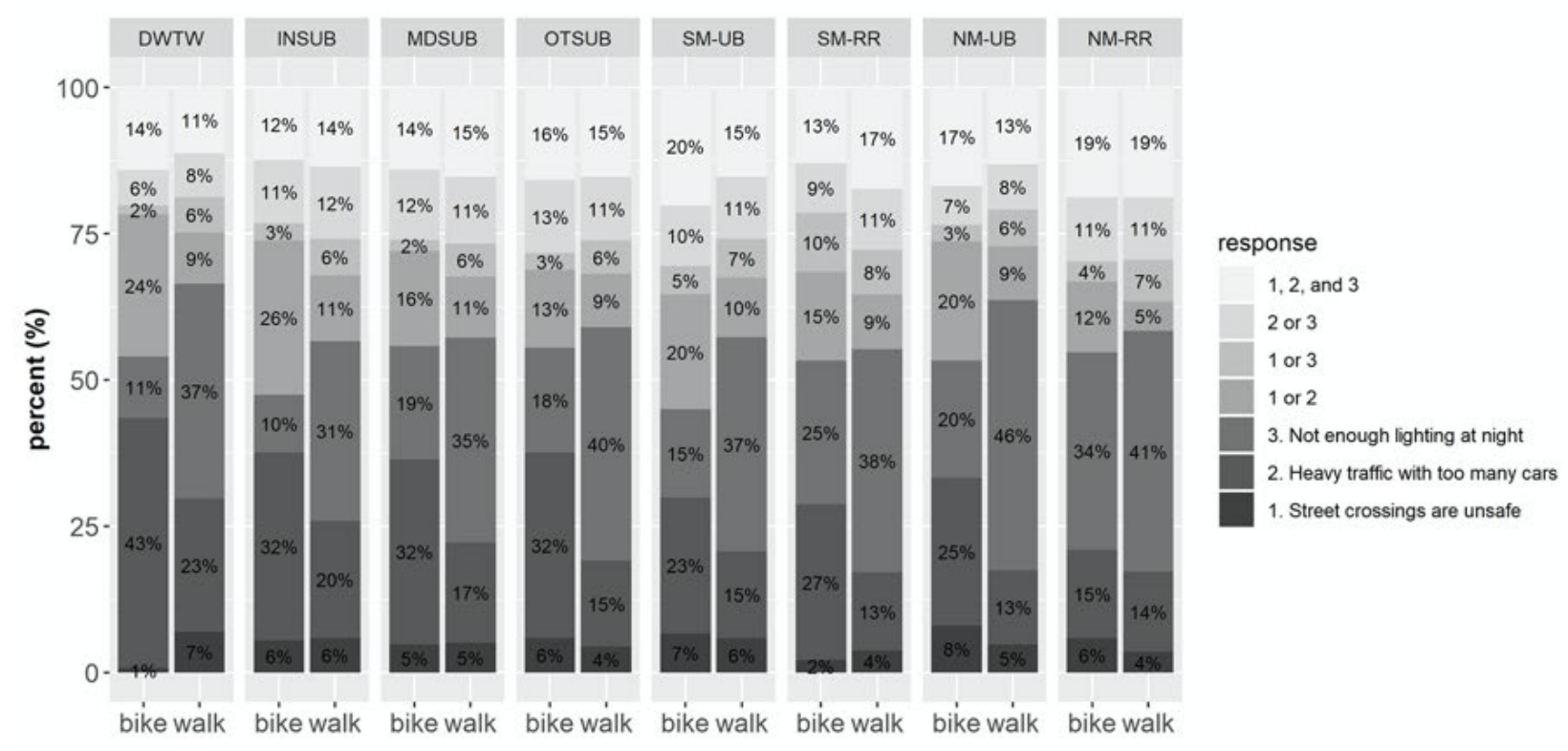

DWTW=downtown, INSUB=inner-suburb, MDSUB=mid-suburb, OTSUB=outer-suburb, SM-UB=small MSA urban, SM-RR=small MSA rural,
NM-UB=not MSA urban, NM-RR=not MSA rural

Figure 3. Barriers to Walking and Biking More 


\section{CONCLUSION}

The study analyzed the spatial disparities in physical activity, particularly transportationrelated physical activity, among eight geographic locations: downtown, inner-suburbs, midring suburbs, and outer-ring suburbs of large metropolitan areas, the urban and rural parts of small metropolitan areas, and the urban and rural parts of non-metropolitan areas.

The descriptive analysis found slight variation of physical activity level between the eight geographic locations. Only slight geographic variation exists in weekly rates of walk and bike trips that are strictly for exercise. There was, however, much more variation in the weekly rates of walk and bike trips that were not for exercise. Residents in the central locations of large metropolitan areas took a significantly larger number of weekly walk and bike trips for non-exercise purposes. The weekly rates of walk and bike trips for nonexercise purposes demonstrated a non-linear relationship with the level of urbanization. Residents in the mid-ring and outer-ring suburbs reported the lowest rates of weekly nonexercise walk and bike trips.

The model results generally confirmed that residents were more physically active when they lived in the areas from the two ends of the urbanization spectrum: inner cities and inner suburbs of large metropolitan areas and the rural parts of non-metropolitan areas. The geographic pattern holds after controlling for neighborhood-level variables. Furthermore, mid-ring and outer-ring suburbanites were not only more likely to report zero walk trips for non-exercise purposes and zero bike trips for both exercise and non-exercise purposes, but also tended to report a smaller number of walk trips for both exercise and non-exercise purposes. Interestingly, rural residents in non-metropolitan areas tended to report a greater number of walk trips for both exercise and non-exercise purposes than mid-ring suburbanites, even after controlling for individual-level and neighborhood-level variables. Rural residents take more walks outside than mid-ring and outer-ring suburbanites. Most extant studies of active travel focused on urban and suburban residents. There is a need for more research to understand how rural residents travel in non-motorized modes and how they manage to take more walk trips than mid-ring and outer-ring suburbanites

Walkers and cyclists in the eight different geographic locations reported different infrastructural and safety barriers that kept them from walking and biking more. For cyclists in the central cities of large metropolitan areas and cyclists in non-metropolitan areas, a lack of nearby paths or trails was the prominent infrastructure barrier to biking more. For suburbanites, a lack of nearby parks seemed to be a more prominent barrier to biking more. No matter which geographic location they lived in, walkers consistently reported no sidewalks or sidewalks in poor condition as the most prominent barriers to walking more. The sidewalk issue was more serious for walkers in suburbs and the urban parts of small metropolitan areas than walkers in other locations. Not enough lighting at night was consistently reported as the most prominent safety barrier to walking more in different geographic locations.

The findings from this study contribute to evidence-based planning of active transportation and public health interventions. The results of this study suggest a few areas in which transportation planning and policies have the potential to promote active travel and physical activity. First, providing complete sidewalks will be an effective tool to promote walking and 
it will work in almost all geographic locations of different levels of urbanicity. Residents in various geographic locations consistently report a lack of sidewalks or sidewalks in poor condition as the primary barriers to walking more. Second, suburbs in large metropolitan areas seem to be the least physically active places and have the largest potential for improvement. Even incremental increases of physical activity in suburbs will generate huge public health benefits, given that more than a half of Americans live in suburbs. In addition to infrastructural barriers, heavy traffic is another primary reason why mid- and outer-ring suburbanites do not ride bicycle more. Lowering speed limits and traffic calming are thus two potential ways to encourage more biking in suburban neighborhoods. Third, in rural areas, improving street lighting and providing more parks seems to be two promising strategies to encourage more biking. 


\section{ABBREVIATIONS AND ACRONYMS}

\begin{tabular}{ll}
\hline ACS & American Community Survey \\
Coef. & Coefficient \\
LEHD & Longitudinal Employer-Household Dynamics \\
MSA & Metropolitan Statistical Area \\
NHTS & National Household Travel Survey \\
TIGER & Topologically Integrated Geographic Encoding and Referencing \\
\hline
\end{tabular}




\section{ENDNOTES}

1. C.A. Myers et al., "Regional Disparities in Obesity Prevalence in the United States: A Spatial Regime Analysis," Obesity 23 (2015): 481-487; A. O'Connor and G. Wellenius, "Rural-urban disparities in the prevalence of diabetes and coronary heart disease," Public Health 126 (2012): 813-820; M. Wen et al., "Rural-Urban Disparities in Obesity Prevalence Among Working Age Adults in the United States: Exploring the Mechanisms," American Journal of Health Promotion 32 (2018): 400-408.

2. F.W. Booth, C.K. Roberts, and M.J. Laye, "Lack of exercise is a major cause of chronic diseases," Comprehensive Physiology 2 (2012): 1143-1211.

3. J.L. Durstine et al., "Chronic disease and the link to physical activity," Journal of Sport and Health Science 2 (2013): 3-11.

4. A.Y. Hansen et al., "Built Environments and Active Living in Rural and Remote Areas: A Review of the Literature," Current Obesity Reports 4 (2015): 484-493.

5. R. Ewing and R. Cervero, "Travel and the Built Environment: A Meta-Analysis," Journal of the American Planning Association 76 (2010): 265-294.

6. A.Y. Hansen et al., "Built Environments and Active Living in Rural and Remote Areas: a Review of the Literature," Current Obesity Reports 4 (2015): 484-493.

7. U.S. Department of Transportation, Federal Highway Administration, National Household Travel Survey (2017), http://nhts.ornl.gov.

8. W. Li et al., "Intrapersonal day-to-day travel variability and duration of household travel surveys: Moving beyond the one-day convention," Journal of Transport and Land Use 11 (2018): 1125-1145.

9. W. Li et al., "Intrapersonal day-to-day travel variability and duration of household travel surveys: Moving beyond the one-day convention," Journal of Transport and Land Use 11 (2018): 1125-1145.

10. C.P. Tribby and D.S. Tharp, "Examining urban and rural bicycling in the United States: Early findings from the 2017 National Household Travel Survey," Journal of Transport \& Health 13 (2019): 143-149.

11. S.A. Carlson et al., "Geographic and Urban-Rural Differences in Walking for Leisure and Transportation," American Journal Preventive Medicine 55 (2018): 887-895.

12. J.R. Olsen et al., "Population Levels Of, And Inequalities In, Active Travel: A National, Crosssectional Study of Adults in Scotland," Preventive Medicine Reports 8 (2017): 129-134.

13. C.E. Short et al., "A Comparison of Correlates Associated With Adult Physical Activity 
Behavior in Major Cities and Regional Settings," Health Psychology, Vol. 33(11), 2014, pp. 1319-1327; V.J. Cleland et al., "Do the Individual, Social, and Environmental Correlates of Physical Activity Differ Between Urban and Rural Women?" Environment and Behavior 44 (2012): 350-373.

14. M.J. Duncan et al., "Geographic Location, Physical Activity and Perceptions of the Environment In Queensland Adults," Health \& Place 15 (2009): 204-209.

15. J.B. Moore et al., "Association of the Built Environment with Physical Activity and Adiposity in Rural and Urban Youth," Preventive Medicine 56 (2013): 145-148.

16. M.C. Nelson et al., "Built and Social Environments: Associations with Adolescent Overweight and Activity," American Journal of Preventive Medicine 31 (2006): 109117.

17. S.L. Martin et al., "Urban, Rural, and Regional Variations in Physical Activity," The Journal of Rural Health 21 (2005): 239-244.

18. S.E. Parks, R.A. Housemann, and R.C. Brownson, "Differential correlates of physical activity in urban and rural adults of various socioeconomic backgrounds in the United States," Journal of Epidemiology and Community Health 57 (2003): 29-35.

19. S. Wilcox et al., "Determinants of leisure time physical activity in rural compared with urban older and ethnically diverse women in the United States," Journal of Epidemiology and Community Health 54 (2000): 667-672.

20. E. Rind and A.P. Jones, "The geography of recreational physical activity in England," Health \& Place 17 (2011): 157-165.

21. J.X. Fan, M. Wen, and L. Kowaleski-Jones, "Rural-Urban Differences in Objective and Subjective Measures of Physical Activity: Findings From the National Health and Nutrition Examination Survey (NHANES) 2003-2006," Preventing Chronic Disease: Public Health Research, Practice, and Policy 11 (2014), E.141.

22. S.A. Carlson et al., "Geographic and Urban-Rural Differences in Walking for Leisure and Transportation," American Journal Preventive Medicine 55 (2018): 887-895.

23. C. McAndrews, K. Okuyama, and J.S. Litt, "The Reach of Bicycling in Rural, Small, and Low-Density Places," Transportation Research Record: Journal of the Transportation Research Board No. 2662 (2017): 134-142.

24. K.C. Heesch, B. Giles-Corti, and G. Turrell, "Cycling For Transport and Recreation: Associations with the Socio-Economic, Natural and Built Environment," Health \& Place 36 (2015): 152-161.

25. J.B. Moore, J. Brinkley, T.W. Crawford, K.R. Evenson, and R.C. Brownson, "Association of the Built Environment with Physical Activity and Adiposity in Rural and Urban Youth," 
Preventive Medicine 56 (2013): 145-148.

26. G.P. Whitfield et al., "National-Level Environmental Perceptions and Walking Among Urban and Rural Residents: Informing Surveillance of Walkability," Preventive Medicine 123 (2019): 101-108.

27. B. Kang et al., "Differences in Behavior, Time, Location, and Built Environment between Objectively Measured Utilitarian and Recreational Walking," Transportation Research Part D 57 (2017): 185-194; Y. Yang and A.V. Diez-Roux, "Walking Distance by Trip Purpose and Population Subgroups," American Journal of Preventive Medicine 43 (2012): 11-19.

28. 2017 NHTS Data User Guide, https://nhts.ornl.gov/documentation.shtml.

29. Lumley, T. (2018). Analysis of Complex Survey Samples, https://cran.r-project.org/ web/packages/survey/survey.pdf. 


\section{BIBLIOGRAPHY}

2017 NHTS Data User Guide. Retrieved on November 10, 2018 from https://nhts.ornl. gov/documentation.shtml.

Booth, F.W., C.K. Roberts, and M.J. Laye. "Lack of Exercise is a Major Cause of Chronic Diseases." Comprehensive Physiology 2 (2012): 1143-1211.

Carlson, S.A., G.P. Whitfield, E.L. Peterson, E.N., Ussery, K.B. Watson, D. Berrigan, and J.E. Fulton. "Geographic and Urban-Rural Differences in Walking for Leisure and Transportation." American Journal Preventive Medicine 55 (2018): 887-895.

Cleland, V.J., K. Ball, A.C. King, and D. Crawford. "Do the Individual, Social, and Environmental Correlates of Physical Activity Differ Between Urban and Rural Women?" Environment and Behavior 44 (2012): 350-373.

Duncan, M.J., W.K. Mummery, R.M. Steele, C. Caperchione, and G. Schofield. "Geographic Location, Physical Activity and Perceptions of the Environment In Queensland Adults." Health \& Place 15 (2009): 204-209.

Durstine, J.L., B. Gordon, Z. Wang, and X. Luo. "Chronic Disease and the Link to Physical Activity." Journal of Sport and Health Science 2 (2013): 3-11.

Ewing, R., and R. Cervero. "Travel and the Built Environment: A Meta-Analysis." Journal of the American Planning Association 76 (2010): 265-294.

Fan, J.X., M. Wen, and L. Kowaleski-Jones. "Rural-Urban Differences in Objective and Subjective Measures of Physical Activity: Findings From the National Health and Nutrition Examination Survey (NHANES) 2003-2006." Preventing Chronic Disease: Public Health Research, Practice, and Policy 11 (2014), E.141.

Hansen, A.Y., M.R.U. Meyer, J.D. Lenardson, and D. Hartley. "Built Environments and Active Living in Rural and Remote Areas: A Review of the Literature." Current Obesity Reports 4 (2015): 484-493.

Heesch, K.C., B. Giles-Corti, and G. Turrell. "Cycling For Transport and Recreation: Associations with the Socio-Economic, Natural and Built Environment." Health \& Place 36 (2015): 152-161.

Kang, B., A.V. Moudonb, P.M. Hurvitzb, and B.E. Saelensc. "Differences in Behavior, Time, Location, and Built Environment between Objectively Measured Utilitarian and Recreational Walking." Transportation Research Part D 57 (2017): 185-194.

Li, W., D. Houston, M.G. Boarnet, and H. Park. "Intrapersonal Day-to-Day Travel Variability and Duration of Household Travel Surveys: Moving beyond the one-day convention." Journal of Transport and Land Use 11 (2018): 1125-1145. 
Lumley, T. Analysis of Complex Survey Samples. 2018. Retrieved on November 10, 2018 from https://cran.r-project.org/web/packages/survey/survey.pdf.

Martin, S.L., G.J. Kirkner, K. Mayo, C.E. Matthews, J. L. Durstine, and J.R. Hebert. "Urban, Rural, and Regional Variations in Physical Activity." The Journal of Rural Health 21 (2005): 239-244.

McAndrews, C., K. Okuyama, and J.S. Litt. "The Reach of Bicycling in Rural, Small, and Low-Density Places." Transportation Research Record: Journal of the Transportation Research Board No. 2662 (2017): 134-142.

Moore J.B., J. Brinkley, T.W. Crawford, K.R. Evenson, and R.C. Brownson. "Association of the Built Environment with Physical Activity and Adiposity in Rural and Urban Youth." Preventive Medicine 56 (2013): 145-148.

Myers, C.A., T. Slack, C.K. Martin, S.T. Broyles, and S.B. Heymsfield. "Regional Disparities in Obesity Prevalence in the United States: A Spatial Regime Analysis." Obesity 23 (2015): 481-487.

Nelson, M.C., P. Gordon-Larsen, Y. Song, B.M. Popkin. "Built and Social Environments: Associations with Adolescent Overweight and Activity." American Journal of Preventive Medicine 31 (2006): 109-117.

O'Connor A., and G. Wellenius. "Rural-urban disparities in the prevalence of diabetes and coronary heart disease." Public Health 126 (2012): 813-820.

Olsen, J.R., R. Mitchell, N. Mutriec, L. Foleyd, and D. Ogilvied. "Population Levels Of, And Inequalities In, Active Travel: A National, Crosssectional Study of Adults in Scotland." Preventive Medicine Reports 8 (2017): 129-134.

Parks, S.E., R.A. Housemann, and R.C. Brownson, "Differential correlates of physical ac-tivity in urban and rural adults of various socioeconomic backgrounds in the United States." Journal of Epidemiology and Community Health 57 (2003): 29-35.

Rind, E., and A.P. Jones, "The Geography of Recreational Physical Activity in England." Health \& Place 17 (2011): 157-165.

Short, C.E., C. Vandelanotte, A. Rebar, and M.J. Duncan. "A Comparison of Correlates Associated With Adult Physical Activity Behavior in Major Cities and Regional Settings." Health Psychology 33 (2014): 1319-1327.

Tribby, C.P., and D.S. Tharp. "Examining Urban and Rural Bicycling in the United States: Early findings from the 2017 National Household Travel Survey." Journal of Transport \& Health 13 (2019): 143-149.

U.S. Department of Transportation, Federal Highway Administration. 2017. National Household Travel Survey. URL: http://nhts.ornl.gov 
Wen, M., J.X. Fan, L. Kowaleski-Jones, and N. Wan. "Rural-Urban Dispar-ities in Obesity Prevalence Among Working Age Adults in the United States: Exploring the Mechanisms." American Journal of Health Promotion 32 (2018): 400-408.

Whitfield, G.P., S.A. Carlson, E.N. Ussery, K.B. Watsona, D. Berriganb, and J.E. Fulton. "National-Level Environmental Perceptions and Walking Among Urban and Rural Residents: Informing Surveillance of Walkability." Preventive Medicine 123 (2019): 101-108.

Wilcox, S., C. Castro, A.C. King, R. Housemann, and R.C Brownson. "Determinants of leisure time physical activity in rural compared with urban older and ethnically diverse women in the United States." Journal of Epidemiology and Community Health 54 (2000): 667-672.

Yang, Y., and A.V. Diez-Roux. "Walking Distance by Trip Purpose and Population Subgroups." American Journal of Preventive Medicine 43 (2012): 11-19. 


\section{ABOUT THE AUTHORS}

\section{HONGWEI DONG}

Dr. Hongwei Dong is an Associate Professor in the Department of Geography and City \& Regional Planning at the California State University Fresno. His research interests include housing, transportation, and healthy cities. His research articles are published in top planning journals such as Journal of the American Planning Association, Journal of Planning Education and Research, Urban Studies, and Journal of Transport Geography. The National Science Foundation (NSF) funded his research on neighborhood environment, physical activity, and mental wellbeing in disadvantaged communities in Fresno.

Gideon Marsh is a graduate student in the Department of Computer Science at the California State University, Fresno. He received his Bachelor degrees in Computer Science and Mathematics-Computer Science from the Southern Oregon University. 


\section{PEER REVIEW}

San José State University, of the California State University system, and the Mineta Transportation Institute (MTI) Board of Trustees have agreed upon a peer review process required for all research published by MTI. The purpose of the review process is to ensure that the results presented are based upon a professionally acceptable research protocol. 


\author{
Founder, Honorable \\ Norman Mineta (Ex-Officio) \\ Secretary (ret.), \\ US Department of Transportation \\ Chair, \\ Abbas Mohaddes (TE 202I) \\ President \& COO \\ Econolite Group Inc. \\ Vice Chair, \\ Will Kempton (TE 2022) \\ Retired \\ Executive Director, \\ Karen Philbrick, PhD \\ (Ex-Officio) \\ Mineta Transportation Institute \\ San José State University \\ Richard Anderson \\ (Ex-Officio) \\ President \& CEO \\ Amtrak \\ David Castagnetti (TE 202 I) \\ Co-Founder \\ Mehlman Castagnetti \\ Rosen \& Thomas \\ Maria Cino (TE 202 I) \\ Vice President \\ America \& U.S. Government \\ Relations Hewlett-Packard Enterprise
}

\author{
Grace Crunican* \\ (TE 2022) \\ Retired
}

Donna DeMartino (TE 202I)

General Manager \& CEO

San Joaquin Regional Transit District

Nuria Fernandez* (TE 2020)

General Manager \& CEO

Santa Clara Valley

Transportation Authority (VTA)

John Flaherty (TE 2020)

Senior Fellow

Silicon Valley American

Leadership Form

Rose Guilbault (TE 2020)

Board Member

Peninsula Corridor

Joint Powers Board

Ian Jefferies (Ex-Officio)

President \& CEO

Association of American Railroads

Diane Woodend Jones

(TE 2022)

Principal \& Chair of Board

Lea + Elliott, Inc.
Therese McMillan

(TE 2022)

Executive Director

Metropolitan Transportation

Commission (MTC)

Bradley Mims (TE 2020)

President \& CEO

Conference of Minority

Transportation Officials (COMTO)

Jeff Morales (TE 2022)

Managing Principal

InfraStrategies, LLC

Dan Moshavi, PhD

(Ex-Officio)

Dean, Lucas College and

Graduate School of Business

San José State University

Takayoshi Oshima (TE 202 I)

Chairman \& CEO

Allied Telesis, Inc.

Toks Omishakin

(Ex-Officio)

Director

California Department of

Transportation (Caltrans)
Paul Skoutelas (Ex-Officio)

President \& CEO

American Public Transportation

Association (APTA)

Dan Smith (TE 2020)

President

Capstone Financial Group, Inc.

Beverley Swaim-Staley (TE 2022)

President

Union Station Redevelopment

Corporation

\section{Jim Tymon (Ex-Officio)}

Executive Director

American Association of

State Highway and Transportation

Officials (AASHTO)

\section{Larry Willis (Ex-Officio)}

President

Transportation Trades

Dept., AFL-CIO

$(\mathrm{TE})=$ Term Expiration

* = Past Chair, Board of Trustees

\section{Directors}

Karen Philbrick, Ph.D.

Executive Director

Hilary Nixon, Ph.D.

Deputy Executive Director

\section{Asha Weinstein Agrawal,}

\section{Ph.D.}

Education Director

National Transportation Finance

Center Director

\section{Brian Michael Jenkins}

National Transportation Security

Center Director

\title{
Research Associates Policy Oversight Committee
}

Jan Botha, Ph.D.

Civil \& Environmental Engineering

San José State University

Katherine Kao Cushing,

\section{Ph.D.}

Enviromental Science

San José State University

Dave Czerwinski, Ph.D. Marketing and Decision Science San José State University
Frances Edwards,

Ph.D.

Political Science

San José State University

Taeho Park, Ph.D.

Organization and Management

San José State University

\section{Christa Bailey}

Martin Luther King, Jr. Library

San José State University

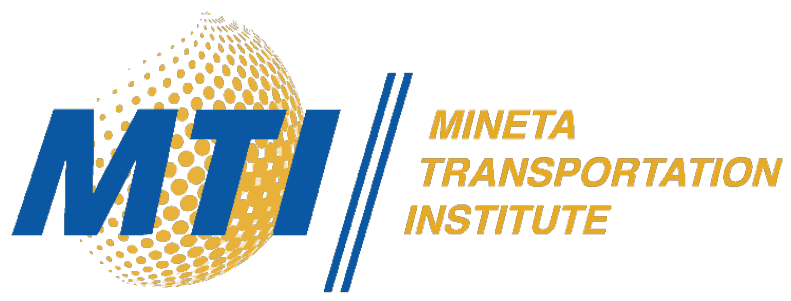

